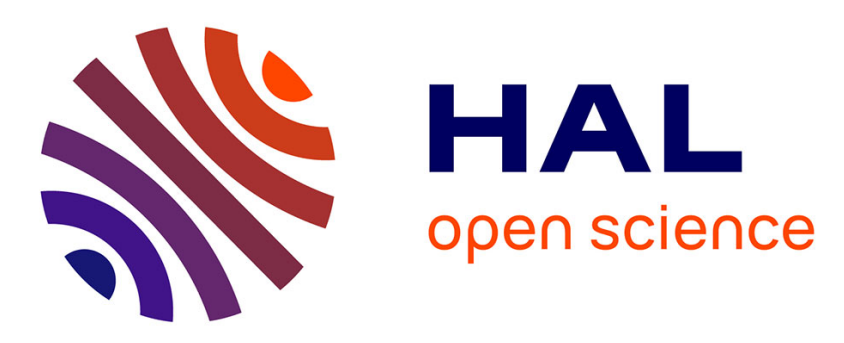

\title{
Synthesis, X-ray crystallography, computational studies and catecholase activity of new zwitterionic Schiff base derivatives
}

\author{
Hakima Boulemche, Barkahem Anak, Amel Djedouani, Rachid Touzani, \\ Michel François, Solenne Fleutot, Franck Rabilloud
}

\section{To cite this version:}

Hakima Boulemche, Barkahem Anak, Amel Djedouani, Rachid Touzani, Michel François, et al.. Synthesis, X-ray crystallography, computational studies and catecholase activity of new zwitterionic Schiff base derivatives. Journal of Molecular Structure, 2019, 1178, pp.606-616. 10.1016/j.molstruc.2018.10.078 . hal-02346045

\section{HAL Id: hal-02346045 \\ https://hal.science/hal-02346045}

Submitted on 12 Mar 2021

HAL is a multi-disciplinary open access archive for the deposit and dissemination of scientific research documents, whether they are published or not. The documents may come from teaching and research institutions in France or abroad, or from public or private research centers.
L'archive ouverte pluridisciplinaire HAL, est destinée au dépôt et à la diffusion de documents scientifiques de niveau recherche, publiés ou non, émanant des établissements d'enseignement et de recherche français ou étrangers, des laboratoires publics ou privés. 


\title{
Synthesis, X-ray crystallography, computational studies and catecholase activity of new zwitterionic Schiff base derivatives
}

\author{
HakimaBoulemche $^{\mathrm{a}, \mathrm{b}}$, Barkahem Anak ${ }^{\mathrm{c}, \mathrm{d}}$,Amel Djedouani ${ }^{\mathrm{a}, \mathrm{c}}$, Rachid Touzani ${ }^{\mathrm{e}}$, \\ Michel François ${ }^{\mathrm{f}}$, Solenne Fleutot ${ }^{\mathrm{f}}$, Franck Rabilloud ${ }^{\mathrm{g}^{*}}$
}

\author{
${ }^{a}$ Laboratoire de Physicochimie Analytique et Cristallochimie des Matériaux Organométalliques et \\ Biomoléculaires, université Constantine 1, 25000 Algérie. \\ ${ }^{b}$ Ecole normale supérieured'enseignement technique, route d'El-Hadaiek,Skikda 21000, Algérie. \\ ${ }^{c}$ Ecole normale supérieure de Constantine, universié Constantine 3, 25000, Algérie. \\ ${ }^{d}$ Laboratoire de Chimie des Matériaux, université Constantine 1, 2500, Algéria. \\ ${ }^{e}$ Laboratoire de Chimie Appliquée et Environnement, LCAE-URAC18, COSTE,Faculté des \\ Sciences, Université Mohamed Premier, BP524, 60000 Oujda, Morocco. \\ ${ }^{f}$ Institut Jean Lamour UMR 7198, Parc de Saurupt, CS 14234 F 54042 Nancy, France. \\ ${ }^{g}$ Univ Lyon, Université Claude Bernard Lyon 1, CNRS, Institut Lumière Matière, F-69622, \\ Villeurbanne, France
}

\begin{abstract}
Three new Schiff bases compounds (L1-L2-L3) were synthesized by a condensation reaction in 1:1 molar ratios of dehydroacetic acid (3-acetyl-6-methyl-2H-pyran-2,4(3H)-dione) and 4-fluoro/4chloro/4-bromo aniline in ethanol, the products were obtained in excellent yields. Their structures were characterized by spectroscopic techniques (FT-IR and 1H-NMR) and single-crystal X-ray diffraction. The three compounds display zwitterionic forms, with cationic iminium and anionic enolate groups.The aromatic ring and dehydroacetic acid ring are in a trans position with respect to the $\mathrm{C}=\mathrm{N}$ bond. Calculations in the framework of the density-functional theory (DFT) were carried out to determine the optimized structures and electronic properties as the HOMO-LUMO energy gap. Hirshfeld surface analysis was used to support the packed crystal lattice 3D network intermolecular forces. The $\mathrm{NH}$ form is found to be more stable than $\mathrm{OH}$ form. On the other hand, the in situ generated copper (II) complexes were examined for their catalytic activities and were found to catalyze the oxidation reaction of catechol to o-quinone under atmospheric dioxygen. The present study reveals that the rate of oxidation depends on the nature of the substituents in the phenyl ring, the counter anion and the concentration of ligand. The combination $\mathrm{L} 1\left(\mathrm{Cu}\left(\mathrm{CH}_{3} \mathrm{COO}\right)_{2}\right)$ gives the highest rate.
\end{abstract}

Keywords:Schiff base; Zwitterionic form; X-Ray; Catecholase; Hirshfeld surface; DFT. 


\section{Introduction}

Schiff bases are important compounds owing to their wide range of biological activities and industrial applications [1,2]. They have also been used as ligands in coordination chemistry[3,4].Nsubstituted $o$-hydroxyimines have been reported to display thermochromism and photochromism in the solid state by $\mathrm{H}$-atom transfer from the hydroxy $\mathrm{O}$ atom to the $\mathrm{N}$ atom, the features of photochromism are used in some application areas such as measuring and controlling radiation intensity, imaging systems and optical computers [5,6]. In general, $O$-hydroxy Schiff bases exhibit two possible tautomeric forms, the phenol-imine (or benzenoid) and keto-amine (or quinoid) forms. Depending on the tautomers, two types of intra-molecular hydrogen bonds are possible: $\mathrm{O}-\mathrm{H} \cdot \cdots \mathrm{N}$ in benzenoid and $\mathrm{N}-\mathrm{H} \cdot \cdots \mathrm{O}$ in quinoidtautomers. $O$-hydroxy Schiff bases have been previously observed in the keto form, in the enol form or in enol/keto mixtures [7,8]. Another form of the Schiff base compounds is also their zwitterionic form [9-12]. Zwitterions of Schiff bases have an ionic intramolecular hydrogen bond $\left(\mathrm{N}^{+}-\mathrm{H} \cdot \cdots \mathrm{O}^{-}\right)$and their $\mathrm{N}^{+}-\mathrm{H}$ bond lengths are longer than the standard interatomic separations observed in neutral $\mathrm{N}-\mathrm{H}$ bonds $(0.87 \AA)$. The other ionic bonds in the zwitterions $\mathrm{C}_{-} \mathrm{O}^{-}$, is not a key indicator as distinctive as $\mathrm{N}^{+}-\mathrm{H}$ bond, because $\mathrm{NH}$ forms of Schiff bases in solid state can be regarded as a resonance hybrid of two canonical structures, the quinoidal and zwitterionic forms [13].

$\mathrm{Cu}(\mathrm{II})$ complexes formed from Schiff base ligands have been important model compounds in studying the physical and chemical behavior of biological copper systems [14]. As an important example, numerous biomimetic approaches were devoted to the synthesis of binuclear $\mathrm{Cu}(\mathrm{II})$ ion complexes with various ligands to reproduce catecholase activity $[15,16]$. Notable progress has been made to mimic catecholase activity using copper complexes coordinated to multidentate Schiff bases ligands [17-19]. It is now well known that proteins containing copper (metal-protein) play a very important role in transport, activation, and metabolism of dioxygen in living organisms [20].

In this paper, we present the full structural characterization and theoretical studies of new zwitterionic Schiff bases : 6-methyl-2-oxo-3-[1-(p-fluoriminio)ethyl]-2H-pyran-4-olate (L1), 6methyl-2-oxo-3-[1-(p-chloriminio)ethyl]-2H-pyran-4-olate (L2) and 6-methyl-2-oxo-3-[1-(pbromoriminio)ethyl]-2H-pyran-4-olate (L3). New copper (II) complex were prepared and evaluated for their catecholase activities at aerobic conditions. Experimental results are compared with theoretical results led in the framework of the density-functional theory. 


\section{Experimental}

\section{1. Materials and physical measurements}

All chemicals were purchased from Sigma- Aldrich and were used without further purification. Thin layer chromatography (TLC) was performed by using Merck silica gel (60 F254) plates (0.25 $\mathrm{mm}$ ) and visualized under Ultraviolet light (UV). Melting points were determined with a digital melting point apparatus using capillary technique. Infrared (IR) spectra were recorded with a Shimadzu FTIR-8010M spectrometer between 400 and $4000 \mathrm{~cm}^{-1}$ (KBr disks). The ${ }^{1} \mathrm{H}$ RMN spectra were recorded on a Jeol GSX WB spectrometer at $270 \mathrm{MHz}$ in $\mathrm{CDCl}_{3}$. The chemical shifts, $\delta$, are given in parts per million (relative to TMS). The UV-Visible spectra were recorded in DMSO between 200-800 nm using JASCO V- 650 spectrophotometer with quartz cells of $1 \mathrm{~cm}$ path length.

\subsection{X-ray crystallographic study}

$\mathrm{X}$-ray single-crystal diffraction data were collected at 293Kfor L1-L2 and $150 \mathrm{~K}$ for L3 on a BrukerAPEX II CCD diffractometer equipped with a graphite monochromator using Mo K $\alpha$ radiation $(\lambda=0.71073 \AA)$. The structures were solved by direct methods using the SIR2002 program [21] and refined on F2 by full matrix least-squares [22]. Unit cell refinement using all observed reflections and data reduction were performed using SAINT. All non hydrogen atoms were refined anisotropically and the hydrogens (except hydrogen atoms attached to $\mathrm{N}$ atom) were included in geometric positions. The hydrogen atoms bound to $\mathrm{N}$ atom were located in difference Fourier map and their coordinates were refined with displacement parameters. The final difference Fourier maps showed no peaks of chemical significance.

\subsection{Computational details}

The ground state of the three compounds have been fully optimized within the Density Functional Theory method[23] (DFT) using the Gaussian09 program package [24].The exchange and correlation functional was modeled within the hybrid Becke's three parameters and the Lee-Yang-Parr function (B3LYP) [25,26]. Atomic basis sets were 6-31+G(d,p) basis set[27].Vibrational frequencies were calculated to guarantee that the optimized structures are local minima. Such a level of approximation was previously shown to be quite adapted for a structural and electronic characterization of molecular complexes.

\subsection{Catecholase activity measurements}


Kinetic measurements were made spectrophotometrically on UV-Vis spectrophotometer, following the appearance of o-quinone over time at $25^{\circ} \mathrm{C}(390 \mathrm{~nm}$ absorbance maximum, $\varepsilon=1600 \mathrm{~L}$ $\mathrm{mol}^{-1} \mathrm{~cm}^{-1}$ in methanol [28]. The complexes were prepared in situ by successively mixing $0.3 \mathrm{~mL}$ of a solution $\left(2.10^{-3} \mathrm{M}\right)$ of $\mathrm{CuX}_{2}, \mathrm{nH}_{2} \mathrm{O}\left(\mathrm{X}=\mathrm{CH}_{3} \mathrm{COO}^{-}, \mathrm{Br}^{-}, \mathrm{Cl}^{-}, \mathrm{NO}_{3}{ }^{-}\right.$, or $\left.\mathrm{SO}_{4}{ }^{2-}\right)$, with $0.15 \mathrm{~mL}$ of a solution $\left(2.10^{-3} \mathrm{M}\right)$ of ligand, then adding $2 \mathrm{~mL}$ of a solution of catechol at a concentration of $10^{-1} \mathrm{M}$.

\subsection{General procedure for synthesis of the Schiff base}

To a hot ethanolic solution $(15 \mathrm{~mL})$ of dehydroaceticacid $(0.01 \mathrm{~mol})$ was added $0.01 \mathrm{~mol}$ of 4 fluoro aniline for (L1),4-chloro aniline for (L2) or 4-bromo aniline for (L3). The resulting solution was refluxed for 3 hand the reaction was monitored by TLC $\left(\mathrm{CH}_{2} \mathrm{Cl}_{2}: \mathrm{MeOH}, 5: 1\right)$. After standing 5 days for (L1) needles crystals were filtered off, washed with small amounts of cold ethanol.(L2) and (L3) were filtered and recrystallized from a mixture of ethanol and a few drops of distilled water,single crystals are obtained after two weeks. The reaction scheme is shown in schema $\mathbf{1}$.

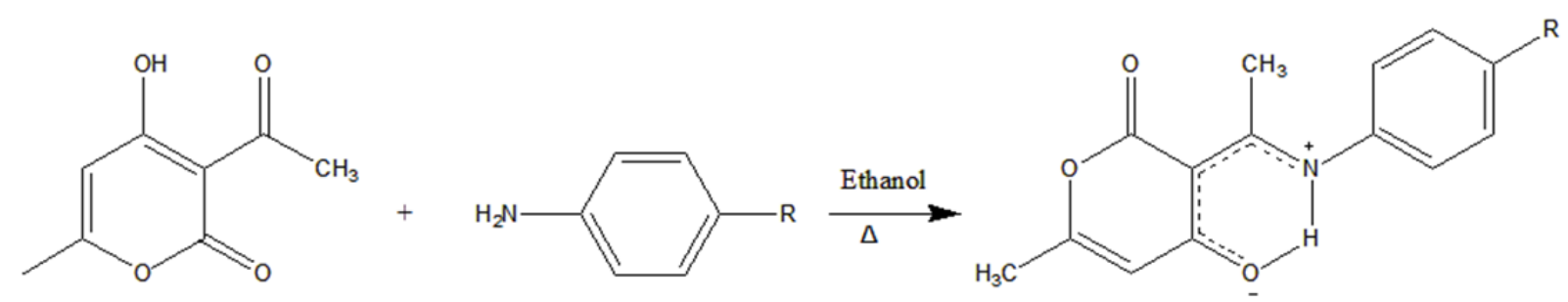

Scheme. 1 The synthesis schematic for L1 $(R=F), \mathbf{L} 2(R=C l)$ and $\mathbf{L 3}(\mathbf{R}=\mathbf{B r})$.

\section{Result and discussion}

\subsection{Analytical data}

3.1.1. (E)-6-methyl-2-oxo-3-[1-(p-fluoriminio)ethyl]-2H-pyran-4-olate(L1): A white crystals were obtained. Yield: $61 \%$, m.p. $410 \mathrm{~K} .{ }^{1} \mathrm{H}$ NMR $\left(\mathrm{CDCl}_{3}\right)$, $\delta$ ppm: 2.15 (s, 3H, $\left.\mathrm{CH}_{3}\right) ; 2.55$ (s, 3H, $\mathrm{CH}_{3 \text { acetyl); }}$ ) $5.75\left(\mathrm{~s}, 1 \mathrm{H}, \mathrm{CH}_{\mathrm{Pyr}}\right)$; the aromatic protons appear as multiple signal in the 7.2-6.5 range; $13.5\left(\mathrm{~s}, H_{\mathrm{O}-}\right.$ $\mathrm{H} \ldots \mathrm{N}$ ).Solubility: Soluble in $\mathrm{MeOH}, \mathrm{DMSO}, \mathrm{DMF}, \mathrm{CHCl}_{3}$ and hot $\mathrm{EtOH}$.

3.1.2. (E)-6-methyl-2-oxo-3-[1-(p-chloriminio)ethyl]-2H-pyran-4-olate (L2):A white solid was obtained. Yield41\%, m.p. $413 \mathrm{~K} .{ }^{1} \mathrm{H}$ NMR $\left(\mathrm{CDCl}_{3}\right), \delta$ ppm: 2.15 (s, 3H, $\left.\mathrm{CH}_{3}\right) ; 2.57$ (s, 3H, $\mathrm{CH}_{3 \text { acetyl }}$ ); $5.74\left(\mathrm{~s}, 1 \mathrm{H}, C H_{\mathrm{Pyr}}\right)$; the aromatic protons appear as multiple signal in the 7.42-6.9 range; $15.3\left(\mathrm{~s}, H_{\mathrm{O}}-\right.$ H...N).Solubility: Soluble in MeOH, DMSO, DMF and hot EtOH. 
3.1.3.(E)-6-methyl-2-oxo-3-[1-(p-bromoriminio)ethyl]-2H-pyran-4-olate(L3): A light beige solid was obtained. Yield48\%,463 K. ${ }^{1} \mathrm{H}$ NMR $\left(\mathrm{CDCl}_{3}\right), \delta$ ppm:2.14 (s, 3H, $\left.\mathrm{CH}_{3}\right) ; 2.63$ (s, 3H, $\left.\mathrm{CH}_{3 \text { acetyl }}\right) ; 5.8$ $\left(\mathrm{s}, 1 \mathrm{H}, C H_{\mathrm{Pyr}}\right)$; the aromatic protons appear as multiple signal in the 7.2-7.7 range; $15.5\left(\mathrm{~s}, H_{\mathrm{O}-\mathrm{H} \ldots \mathrm{N}}\right)$. Solubility: Soluble in MeOH, DMSO, DMF and hot EtOH.

\subsection{Infrared spectra}

Infrared spectra of the three compounds are found to be quite similar. A zwitterionic form was observed in the solid state for the three Compounds (see crystallographic data in the following paragraph).The IR spectra data of molecules taken from $\mathrm{KBr}$ pellet, are in agreement with the structure determined by the X-ray diffraction. The bands appearing around $3400 \mathrm{~cm}^{-1}$ are assigned to the O-...H-N ${ }^{+}$stretching [29]. The $v(\mathrm{C}=\mathrm{N})$ absorption bands are observed at 1555 and $1570 \mathrm{~cm}^{-1}$ for L1, L2 and L3 respectively as ArCH=Nar [30,31]. On the other hand, the bands observed between 1207 and $1275 \mathrm{~cm}^{-1}$ are assigned to $\mathrm{vC}-\mathrm{O}$ (phenolic) frequencies [32,33]. The absorption peak around $1610 \mathrm{~cm}^{-1}$ is due to the $\mathrm{CO}$ stretching; the value appears to be lower than that for a typical $\mathrm{C}=\mathrm{O}$ group (1712-1708 cm-1) and is indicate of the enolic form of the molecules, in which the proton is transferred from the oxygen atom to the nitrogen atom.

\subsection{UV-Vis analysis}

The UV-Vis absorption spectra show one bands at 326, 331, and $330 \mathrm{~nm}$ for L1, L2, L3 compounds respectively, which might be assigned to the $\pi-\pi^{*}$ transitions [34].

\subsection{Crystallographic studies of ligands}

The main crystal parameters are reported in Table 1 . The bond distances and angles are listed in Table 2. The numbering schema and a displacement ellipsoid plot of L1, L2 and L3 are showed in Fig 1. (L1) is crystallized in a monoclinic system in P21/c space group and with a four unit per cell $(Z=4),(\mathbf{L 2})$ crystallized in a triclinic system in $\mathrm{P}-1$ space group and with a two unit per cell $(\mathrm{Z}=2)$ and (L3) crystallized in anorthorhombic system in Pnab space group and with eight unit per cell $(\mathrm{Z}=$ $8)$. 


\section{Table 1}

Crystallographic data and structure refinement details for L1, L2 and L3.

\begin{tabular}{|c|c|c|c|}
\hline Compound & $L 1$ & $L 2$ & $L 3$ \\
\hline Empirical formula & $\mathrm{C}_{14} \mathrm{H}_{12} \mathrm{O}_{3} \mathrm{NF}$ & $\mathrm{C}_{14} \mathrm{H}_{12} \mathrm{O}_{3} \mathrm{NCl}$ & $\mathrm{C}_{14} \mathrm{H}_{12} \mathrm{O}_{3} \mathrm{NBr}$ \\
\hline Formula weight, g/mol & 261.25 & 277.70 & 322.16 \\
\hline Crystal description & Needle & Needle & Prism \\
\hline Space group & $\mathrm{P} 21 / \mathrm{c}$ & $\mathrm{P}-1$ & Pnab \\
\hline Crystal system & Monoclinic & Triclinic & Orthorhombic \\
\hline $\mathrm{F}(000)$ & 544 & 288 & 1296 \\
\hline \multicolumn{4}{|c|}{ Unit cell dimensions } \\
\hline $\mathrm{a} / \AA$ & $4.0119(3)$ & $7.5606(5)$ & $9.6906(2)$ \\
\hline $\mathrm{b} / \AA$ & $23.6690(17)$ & $8.7382(7)$ & $9.9780(3)$ \\
\hline $\mathrm{c} / \AA$ & $12.8177(10)$ & $10.2086(12)$ & $26.7807(9)$ \\
\hline$\alpha /^{\circ}$ & 90 & $85.018(4)$ & 90 \\
\hline$\beta /{ }^{\circ}$ & $94.494(2)$ & $79.311(3)$ & 90 \\
\hline$\gamma /{ }^{\circ}$ & 90 & $76.008(8)$ & 90 \\
\hline $\mathrm{V} / \AA^{3}$ & $1213.40(16)$ & $642.45(10)$ & $2589.50(13)$ \\
\hline $\mathrm{Z}$ & 4 & 2 & 8 \\
\hline Temperature/K & $293(2)$ & $293(2)$ & $150(2)$ \\
\hline $\begin{array}{l}\text { Orangefordata } \\
\text { collection }\left(^{\circ}\right)\end{array}$ & $1.72-25.69$ & $2.03-25.58$ & $3.03 / 27.36$ \\
\hline Radiation & Mo $\mathrm{K} \alpha(\lambda=0.71073)$ & Mo $\mathrm{K} \alpha(\lambda=0.71073)$ & Mo $\mathrm{K} \alpha(\lambda=0.71073)$ \\
\hline Dcalcd $\left(\mathrm{g} / \mathrm{cm}^{-3}\right)$ & 1.430 & 1.436 & 1.653 \\
\hline$\mu\left(\mathrm{mm}^{-1}\right)$ & 0.111 & 0.300 & 3.178 \\
\hline Range/indices $(\mathrm{h}, \mathrm{k}, \mathrm{l})$ & $\begin{array}{c}-4 \leq \mathrm{h} \leq 4 \\
-28 \leq \mathrm{k} \leq 28 \\
-15 \leq 1 \leq 15\end{array}$ & $\begin{array}{c}-8 \leq \mathrm{h} \leq 8 \\
-10 \leq \mathrm{k} \leq 9 \\
-12 \leq 1 \leq 12\end{array}$ & $\begin{array}{c}-8 \leq \mathrm{h} \leq / 12 \\
-12 \leq \mathrm{h} \leq 12 \\
-34 \leq 1 \leq / 21\end{array}$ \\
\hline $\begin{array}{c}\text { Ref Nmb of reflections } \\
\text { measured }\end{array}$ & 118724 & 4176 & 11767 \\
\hline $\begin{array}{c}\text { Number of independent } \\
\text { reflections }\end{array}$ & 2280 & 2248 & 2945 \\
\hline reflections with $\mathrm{I}>2 \sigma(\mathrm{I})$ & 1503 & 1059 & 2309 \\
\hline Number of parameters & 209 & 173 & 174 \\
\hline Refinement method & $\begin{array}{c}\text { Full-matrix } \\
\text { least-squares on F2 }\end{array}$ & $\begin{array}{c}\text { Full-matrix } \\
\text { least-squares on F2 }\end{array}$ & $\begin{array}{c}\text { Full-matrix } \\
\text { least-squares on F2 }\end{array}$ \\
\hline Goodness-of-fit (GOF) & 0.966 & 0.971 & 0.955 \\
\hline $\mathrm{R}[\mathrm{F} 2>2 \sigma(\mathrm{F} 2)]$ & 0.0336 & 0.1082 & 0.0403 \\
\hline$w R(F 2)$ & 0.1311 & 0.1745 & 0.068 \\
\hline Rint & 0.0519 & 0.0673 & 0.0293 \\
\hline $\operatorname{Max} / \min \delta p\left(\mathrm{e} / \AA^{3}\right)$ & $0.290 /-0.287$ & $0.379 /-0.374$ & $0.062 /-0.308$ \\
\hline
\end{tabular}




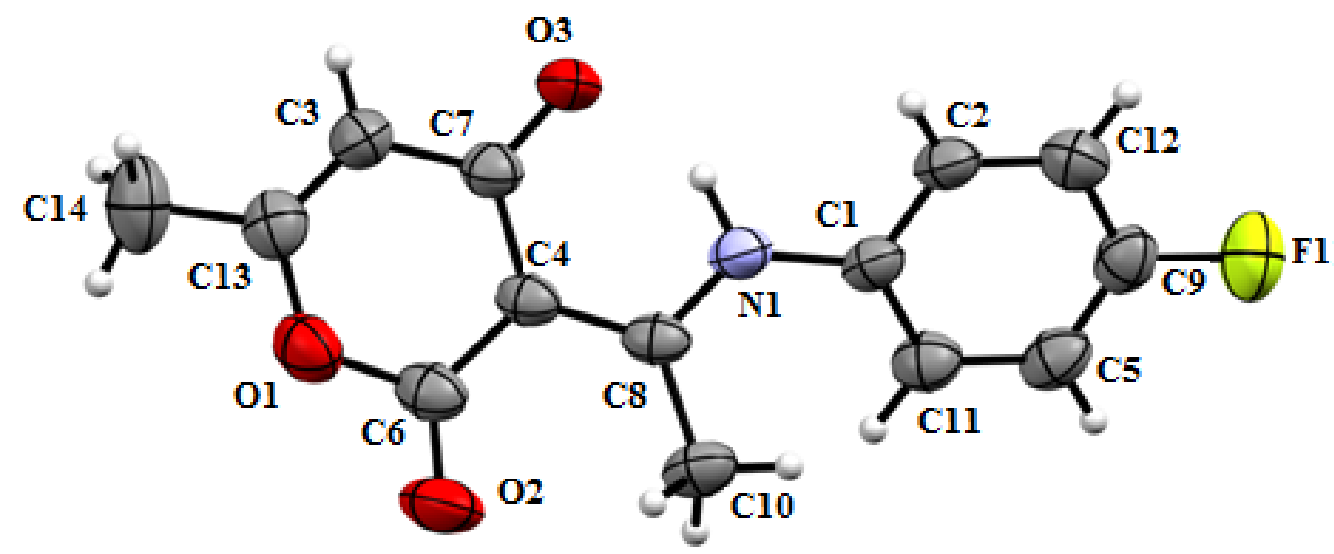

L1

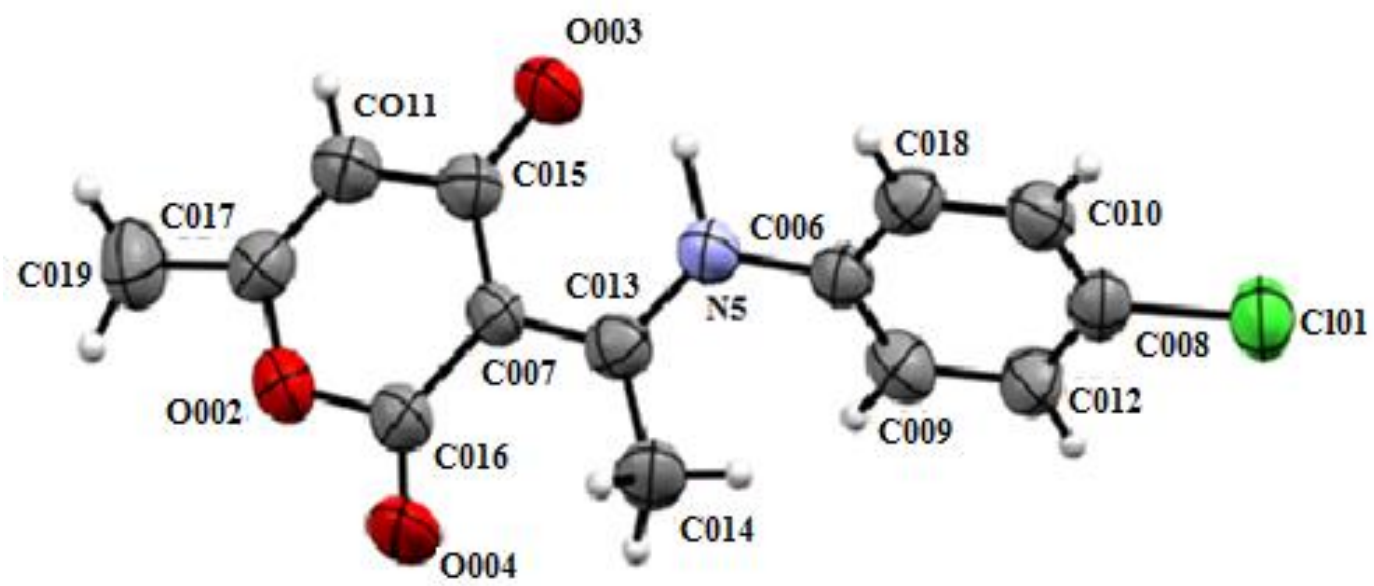

L2

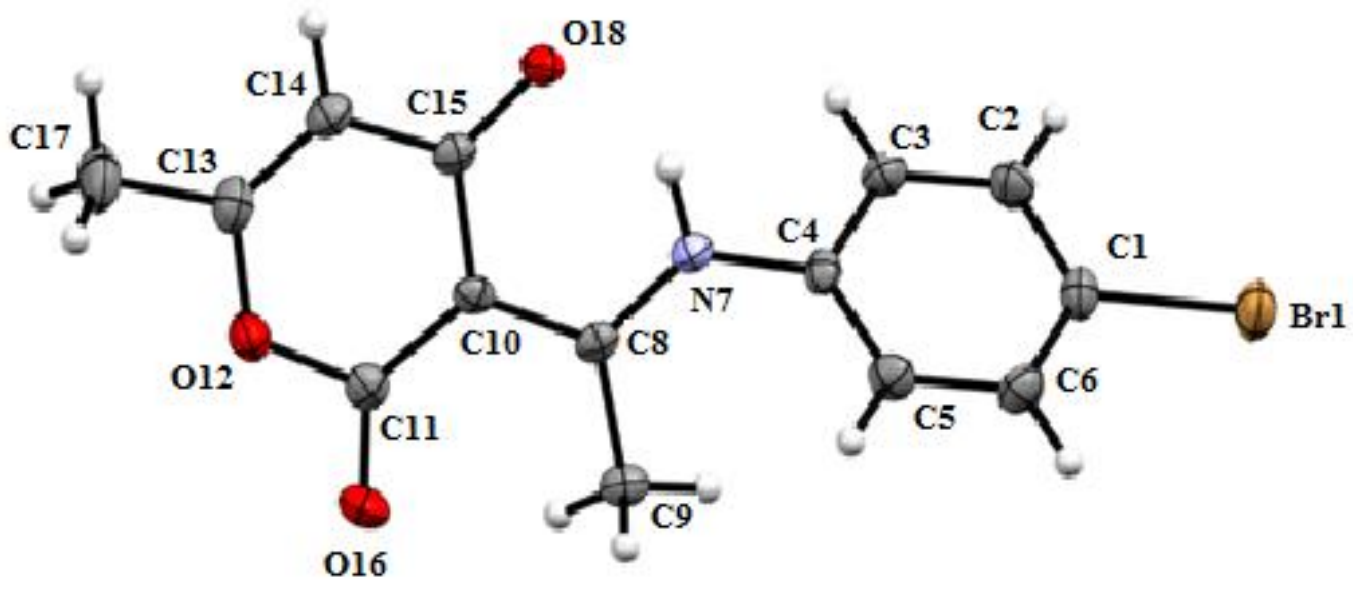

L3

Fig. 1 View of the molecular structure of L1, L2 and L3 with the atom labeling. 
The structures reported here adopt a zwitterionic form, with the phenolic $\mathrm{H}$ atom having been transferred to the imino group. The $\mathrm{H}$ atom attached to $\mathrm{N}$ was located in a difference-Fourier map and freely refined. The resulting iminium and hydroxyl groups are linked by an intramolecular NH...O hydrogen bond [0.90, 1.091 and $0.880 \AA]$ for L1, L2 and L3 respectively, comparable with the similar zwitterions in the literature [35,36]. The bond distances shown in Table 2 indicate that the C$\mathrm{N}_{\text {iminium }}$ bond length of [1.325(3), 1.352(6) and 1.325(3) $\AA$ ] in three compounds L1, L2 and L3, respectively, agree with similar bond in related compounds 1-Dimethylamino-3-dimethyliminio-2(p-methoxyphenyl)prop-1-ene perchlorate and 1-Dimethylamino-3-dimethylimino-1-phenylprop-1ene perchlorate [37,38]. This distance is slightly longer than a typical $\mathrm{C}=\mathrm{N}$ bond (1.269 $\AA$ ) [39], but much shorter than the single carbon-nitrogen(1.409 $\AA$ ) [40], because of the resonance. The $\mathrm{C}-\mathrm{O}_{\text {Hydroxy }}$ bond length [1.260(3), 1.274(5) and 1.260 (2) $\AA$ ] respectively are intermediate between single and double carbon to oxygen bond lengths (1.362 $⿱$, $1.222 \AA$ ) [41]. The carbon-carbon bonds connecting the enol and imine groups exhibit intermediate distances between a single and a double bond (Table 2), indicating the zwitterionic character of the title compounds [42].

In the three compounds, the aromatic ring and dehydroacetic acid ring are in trans position with respect to the $\mathrm{C}=\mathrm{N}$ bond, and the molecular configuration is determined by the presence of the intramolecular hydrogen bond $\mathrm{O}^{-} \ldots \mathrm{H}_{-} \mathrm{N}^{+}$. The three molecules differ in the orientation of phenyl rings. In L1 the dihedral angle between the two rings of aromatic and dehydroacetic acid is $37.35^{\circ}$, while it is $68.18^{\circ}$ and $51.23^{\circ}$ in the case of $\mathrm{L} 2$ and $\mathrm{L} 3$ respectively. The iminium atom $\mathrm{H}$ participates in a strong intramolecular hydrogenbond with the enolate atom $\mathrm{O}$, which generates aS(6) ring motif [43]. Similar intramolecular hydrogen bonds were reported in the above-mentioned zwitterionic phenolates $[44,45]$. This six-membered pseudocycle is almost planar, the maximum deviation from the mean plane being $0.018 \AA$ for atom C4 in L1, and 0.109 for atom $\mathrm{N}$ in L2 and 0.021 in L3 for atom $\mathrm{H} 7$.

In the crystal, molecules of L1 are aligned head to foot along b axis, in columns parallel to [0 0 1] axis and the structure is stabilized by three kinds of $\mathrm{C}-\mathrm{H} \cdots \mathrm{O}$ interactions. This arrangement separates the equivalent groups in columns by 4.012 (1) $\AA$ (Fig. 4, Table 3).

Molecules of L2 exhibit one intermolecular hydrogen bond N5-H2...O3. In the crystal, molecules are aligned along c axis; forming layers that extend in zigzag parallel to the plane (b, c) (see Fig. 5). There are no other significant intermolecular contacts. In the crystal packing of L3, the structure is stabilized by four kinds of $\mathrm{C}-\mathrm{H} \cdots \mathrm{O}$ interactions alternating zigzag chains along the $\mathrm{c}$ axis (Fig. 6, Table 3). 
Table 2

Selected bond distances $(\AA)$ and angles $\left(^{\circ}\right)$ for ligands.

\begin{tabular}{|c|c|c|c|}
\hline \multicolumn{2}{|c|}{ Bond lengths $(\AA)$} & \multicolumn{2}{|c|}{ Bond angles $\left({ }^{\circ}\right)$} \\
\hline \multicolumn{4}{|l|}{ L1 } \\
\hline $\begin{array}{l}\text { F1-C9 } \\
\text { O3-C7 } \\
\text { C4-C8 } \\
\text { C4-C7 } \\
\text { N1-C8 } \\
\text { N1-H12 } \\
\end{array}$ & $\begin{array}{l}1.359(3) \\
1.260(3) \\
1.419(4 \\
1.440(4) \\
1.325(3) \\
0.90(3) \\
\end{array}$ & $\begin{array}{l}\text { C8-N1-H12 } \\
\text { C8-C4-C7 } \\
\text { O3-C7-C4 } \\
\text { N1-C8-C4 }\end{array}$ & $\begin{array}{l}110.3(19) \\
121.7(2) \\
123.1(2) \\
117.3(2)\end{array}$ \\
\hline \multicolumn{4}{|l|}{$\mathbf{L 2}$} \\
\hline $\begin{array}{l}\text { Cl01-C008 } \\
\text { O003-C015 } \\
\text { N005-C013 } \\
\text { C007-C015 } \\
\text { C00-C013 } \\
\text { N005-H2 }\end{array}$ & $\begin{array}{l}1.731(5) \\
1.274(5) \\
1.352(6) \\
1.417(6) \\
1.431(6) \\
1.090\end{array}$ & $\begin{array}{l}\mathrm{C} 015-\mathrm{C} 007-\mathrm{C} 013 \\
\text { N005-C013-C007 } \\
\text { O003-C015-C007 } \\
\text { H3-N05-C013 }\end{array}$ & $\begin{array}{l}121.4(4) \\
117.2(4) \\
123.5(4) \\
120.55\end{array}$ \\
\hline \multicolumn{4}{|l|}{$\mathbf{L 3}$} \\
\hline $\begin{array}{l}\text { Br1-C1 } \\
\text { N7-C8 } \\
\text { C8-C10 } \\
\text { C10-C15 } \\
\text { C15-O18 } \\
\text { N7-H7 }\end{array}$ & $\begin{array}{l}1.900(2) \\
1.322(3) \\
1.433(3) \\
1.451(3) \\
1.260(2) \\
0.88\end{array}$ & $\begin{array}{l}\text { C8- N7-H7 } \\
\text { N7-C8-C10 } \\
\text { C8-C10-C15 } \\
\text { O18-C15-C10 }\end{array}$ & $\begin{array}{l}115.1 \\
117.30(17) \\
120.33(18) \\
123.60(18)\end{array}$ \\
\hline
\end{tabular}

\section{Table 3}

Distances $(\AA)$ and angles $\left(^{\circ}\right)$ of hydrogen bond for L1, L2 and L3.

\begin{tabular}{|c|c|c|c|c|}
\hline D-H...A & $\mathrm{d}(\mathrm{D}-\mathrm{H})$ & $d(H \ldots A)$ & $\mathrm{d}(\mathrm{D}-\mathrm{A})$ & D-H-A \\
\hline \multicolumn{5}{|l|}{ L1 } \\
\hline $\mathrm{N} 1-\mathrm{H} 12 \ldots \mathrm{O} 3$ & $0.91(3)$ & $1.72(3)$ & $2.545(3)$ & $150(3)$ \\
\hline $\mathrm{C} 12-\mathrm{H} 1 \ldots \mathrm{O} 2$ & $0.92(3)$ & $2.49(3)$ & $3.236(3)$ & $139(2)$ \\
\hline $\mathrm{C} 10-\mathrm{H} 5 \ldots \mathrm{O} 2$ & $0.94(3)$ & $2.30(3)$ & $2.762(4)$ & $109(2)$ \\
\hline $\mathrm{C} 10-\mathrm{H} 6 \ldots \mathrm{O} 3$ & $1.04(4)$ & $2.40(4)$ & $3.311(4)$ & $145(3)$ \\
\hline \multicolumn{5}{|l|}{ L2 } \\
\hline $\mathrm{N} 005-\mathrm{H} 2 \ldots \mathrm{O} 003$ & 1.0900 & 1.7400 & $2.535(5)$ & 126.00 \\
\hline \multicolumn{5}{|l|}{ L3 } \\
\hline N7-H7 ...O18 & 0.8800 & 1.7600 & $2.528(2)$ & 144.00 \\
\hline $\mathrm{C} 3-\mathrm{H} 3 \ldots \mathrm{O} 16$ & 0.9500 & 2.5700 & $3.472(3)$ & 158.00 \\
\hline C9-H9B...O16 & 0.9800 & 2.3100 & $2.787(3)$ & 109.00 \\
\hline C9-H9C...O18 & 0.9800 & 2.4900 & $3.252(2)$ & 134.00 \\
\hline C14-H14...O16 & 0.9500 & 2.5800 & $3.524(3)$ & 172.00 \\
\hline
\end{tabular}




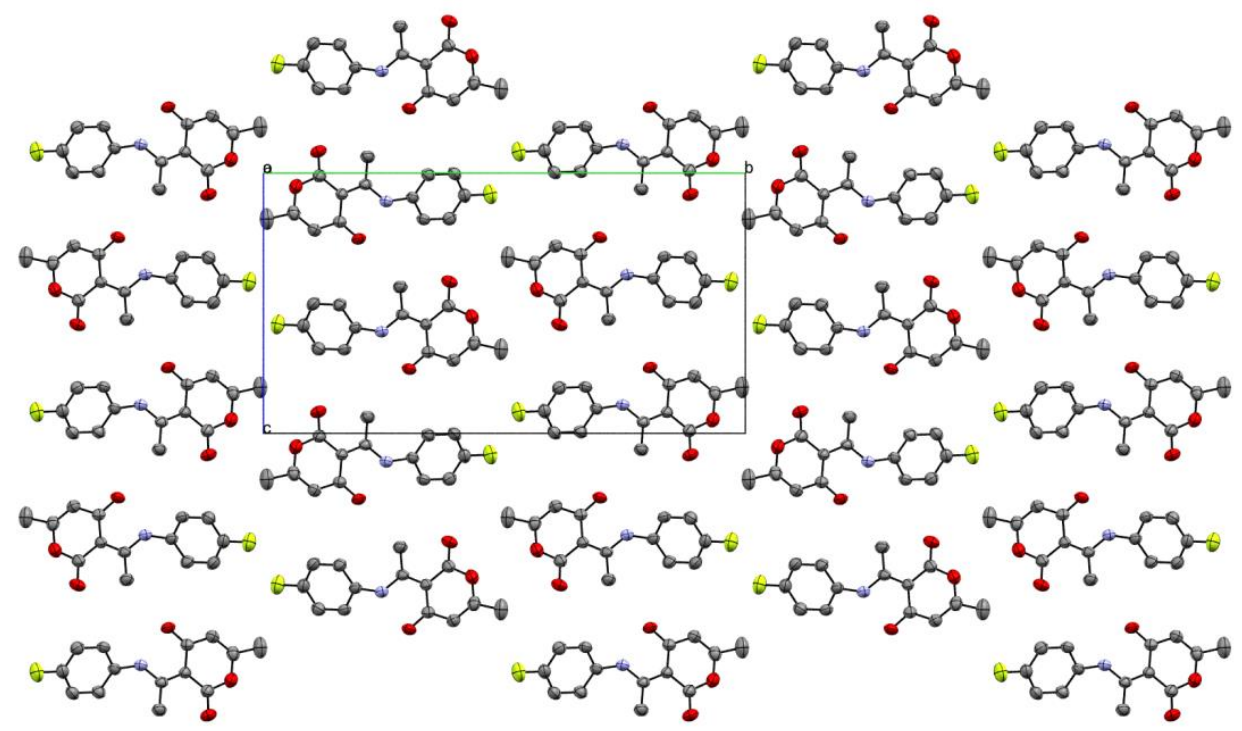

(a)

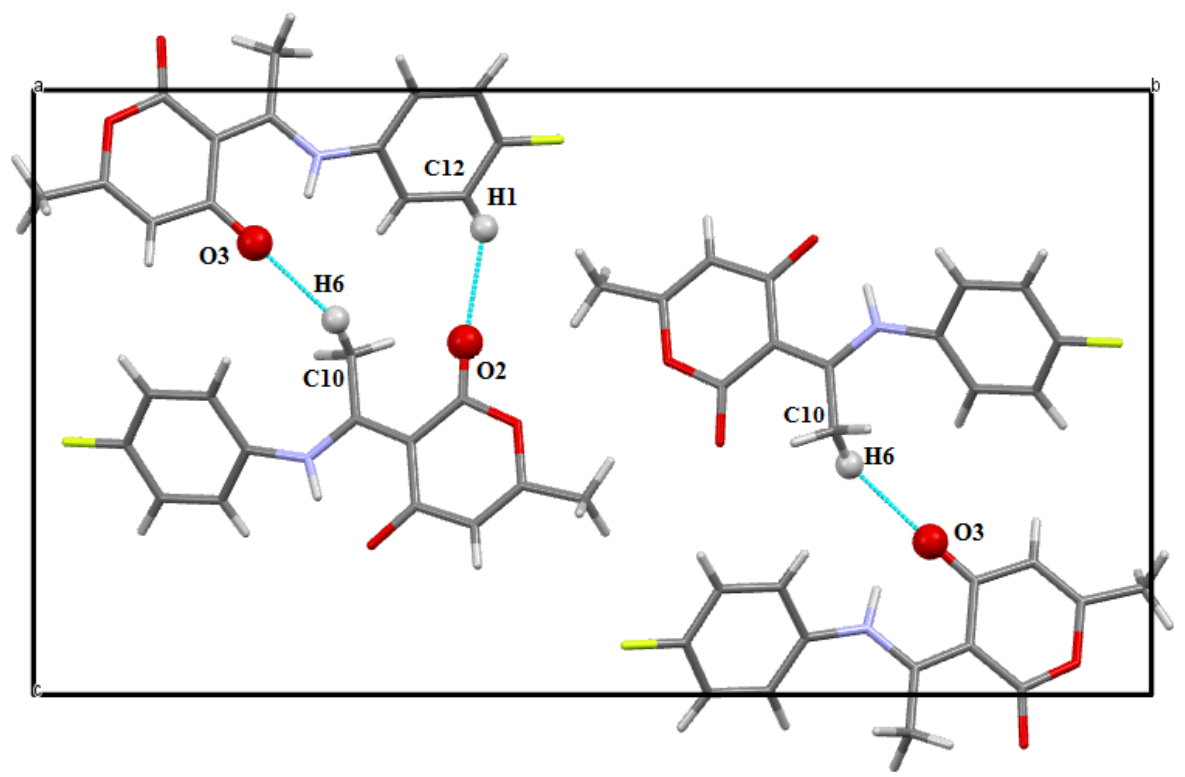

(b)

Fig. 2 Cell packing. $\mathrm{H}$ atoms have been omitted for clarity (a) and hydrogen bonding (b) for $\mathbf{L} \mathbf{1}$. 


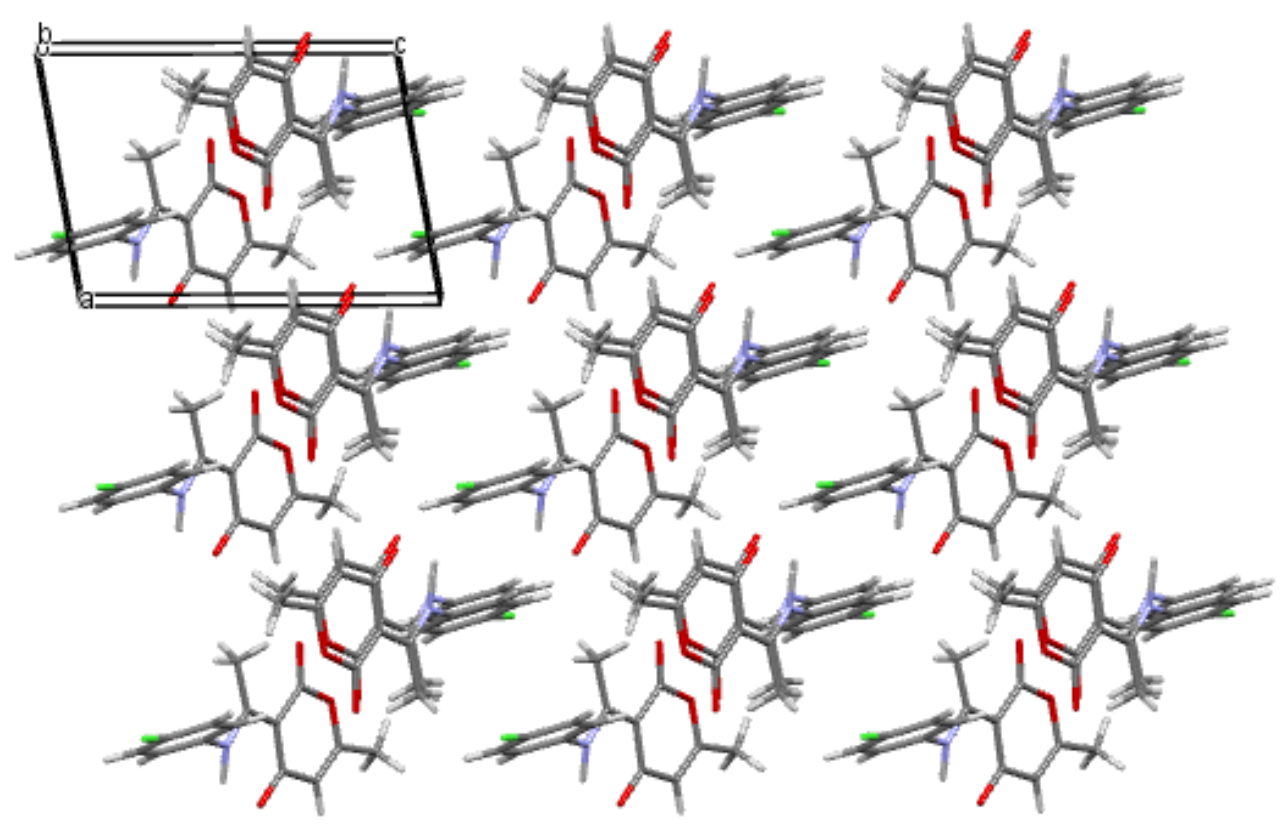

Fig. 3 Cell packing for $\mathbf{L} 2$.

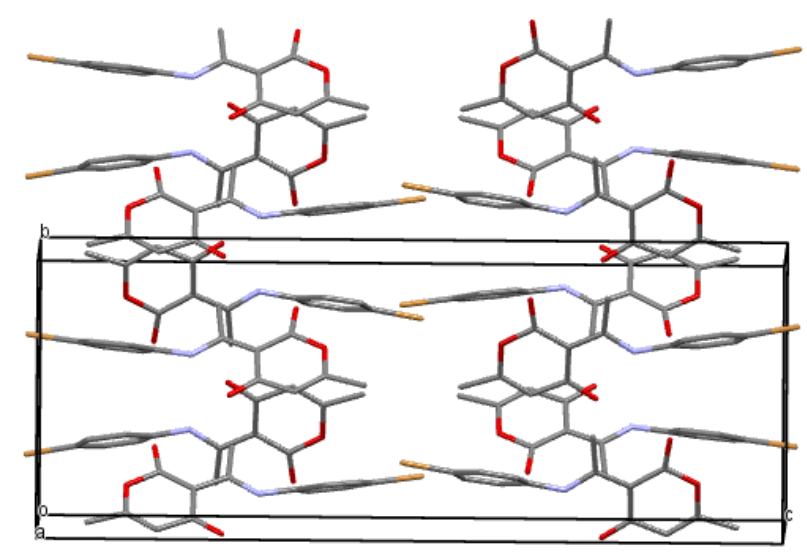

(a)

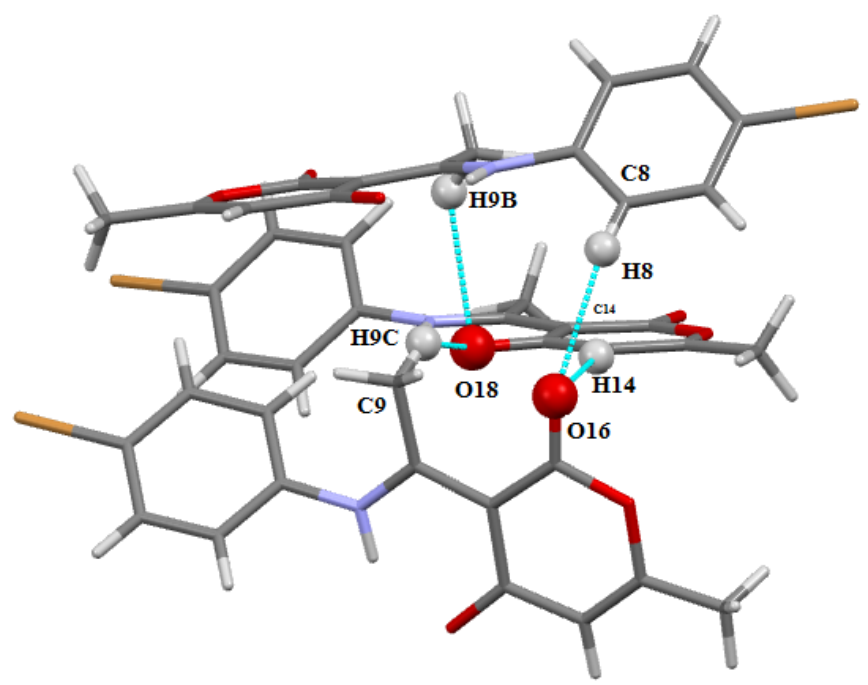

(b)

Fig. 4 Cell packing. $\mathrm{H}$ atoms have been omitted for clarity (a) and hydrogen bonding (b) for $\mathbf{L 3}$. 


\subsection{Computational Study}

Table 4.

Bond lengths $(\AA)$ and angles $\left(^{\circ}\right)$ for $\mathbf{L 1}, \mathbf{L 2}$ and L3.Experimental data are given in parentheses (in bold). $\mathrm{X}$ designs the halogen atom $(\mathrm{X}=\mathrm{Br}, \mathrm{Cl}$ and $\mathrm{F})$.

\begin{tabular}{|c|c|c|c|}
\hline Bond length $(\AA)$ & L1 & $\mathbf{L 2}$ & L3 \\
\hline $\mathrm{X}(1)-\mathrm{C}(2)$ & $1.357 \quad \mathbf{( 1 . 3 5 9 )}$ & 1.755 (1.731) & $1.900 \quad(\mathbf{1 . 9 0 0 )}$ \\
\hline $\mathrm{C}(7)-\mathrm{N}(12)$ & $1.422 \quad(\mathbf{1 . 4 2 2})$ & $1.420(\mathbf{1 . 4 3 6})$ & $1.419 \quad(\mathbf{1 . 4 1 7})$ \\
\hline $\mathrm{C}(14)-\mathrm{C}(19)$ & $1.341 \quad$ (1.324) & 1.341 (1.351) & $1.341 \quad$ (1.321) \\
\hline $\mathrm{C}(19)-\mathrm{C}(25)$ & $1.464 \quad$ (1.442) & 1.464 (1.435) & $1.464 \quad(\mathbf{1 . 4 5 1 )}$ \\
\hline $\mathrm{C}(19)-\mathrm{O}(31)$ & $1.258 \quad(\mathbf{1 . 2 1 0})$ & 1.258 (1.212) & $1.258 \quad$ (1.259) \\
\hline $\mathrm{N}(12)-\mathrm{H}(13)$ & 1.042 (0.904) & 1.042 (1.043) & $1.042 \quad(\mathbf{0 . 8 7 9})$ \\
\hline \multicolumn{4}{|l|}{ Angle $\left(^{\circ}\right)$} \\
\hline $\mathrm{C}(7)-\mathrm{N}(12)-\mathrm{H}(13)$ & 118.30 (118.90) & 118.17 (124.90) & 118.13 (115.14) \\
\hline $\mathrm{H}(13)-\mathrm{N}(12)-\mathrm{C}(14)$ & $112.51 \quad(\mathbf{1 1 0 . 4 4 )}$ & 112.42 (114.37) & 112.41 (115.10) \\
\hline $\mathrm{C}(7)-\mathrm{N}(12)-\mathrm{C}(14)$ & 129.16 (130.63) & 129.38 (124.90) & 129.45 (129.75) \\
\hline $\mathrm{C}(19)-\mathrm{C}(25)-\mathrm{O}(31)$ & 123.26 (128.09) & $123.24(\mathbf{1 3 0 . 4 2 )}$ & $123.23(\mathbf{1 2 3 . 6 0})$ \\
\hline
\end{tabular}

The DFT-optimized parameters (bond lengths, angles) are given in Table 4. They are in good agreement with the experimental data. The calculated bond distance $\mathrm{C}(19)-\mathrm{C}(25)$ is slightly longer than experimental values within 0.013-0.029 $\AA$ for the three compounds. The calculated C-N and C$\mathrm{O}$ bond distances for the three compounds which are most important of tautometric forms, are also in good agreement with experiment, since $\mathrm{C}(7)-\mathrm{N}(12)$ and $(\mathrm{C} 19)-\mathrm{O}(31)$ bond distances are slightly longer than experimental values within 0.002-0.016 $\AA$ and 0.001-0.048 $\AA$ for L2 and L3 respectively. The calculated bond angles for the three compounds with B3LYP levels are all very similar to the experimental values with slight deviations within $0.6-7.18^{\circ}$. These results are in agreement with the expect delocalization in the molecule and confirmed by a bond angle $\mathrm{C}(7)-\mathrm{N}(12)-\mathrm{C}(14) \sim 129^{\circ}$ showing a $\mathrm{sp}^{2}$ hybridization on the $\mathrm{N}(12)$ atom.

\subsection{Frontier molecular orbitals (FMOs)}


The frontier molecular orbitals (FMOs) play an important role in the electric proprieties. The energy gap between the highest occupied molecular orbital (HOMO) and the lowest unoccupied molecular orbital (LUMO) is an indicator of the stability and optical polarizability of a molecule.

The Schiff bases display two possible forms of intermolecular hydrogen bonds: the phenol-imine $(\mathrm{OH})$, and Keto-amine (NH) forms (fig. 5). The contour plot and energy of frontier orbitals HOMO and LUMO for the two forms are reproduced in fig. 5.

The keto-amine $(\mathrm{NH})$ forms which were preferably compared with phenol-imine $(\mathrm{OH})$ forms decrease the HOMO level and increase the LUMO level implying a more stability. The electronic structure for the phenol-imine $(\mathrm{OH})$ shows an intra-ligand charge transfer from HOMO to LUMO, while the keto-amine ( $\mathrm{NH}$ ) forms have a charge transfer $\pi-\pi^{*}$ (fig. 5). Clearly the keto-amine form is in agreement with stability of three compounds.

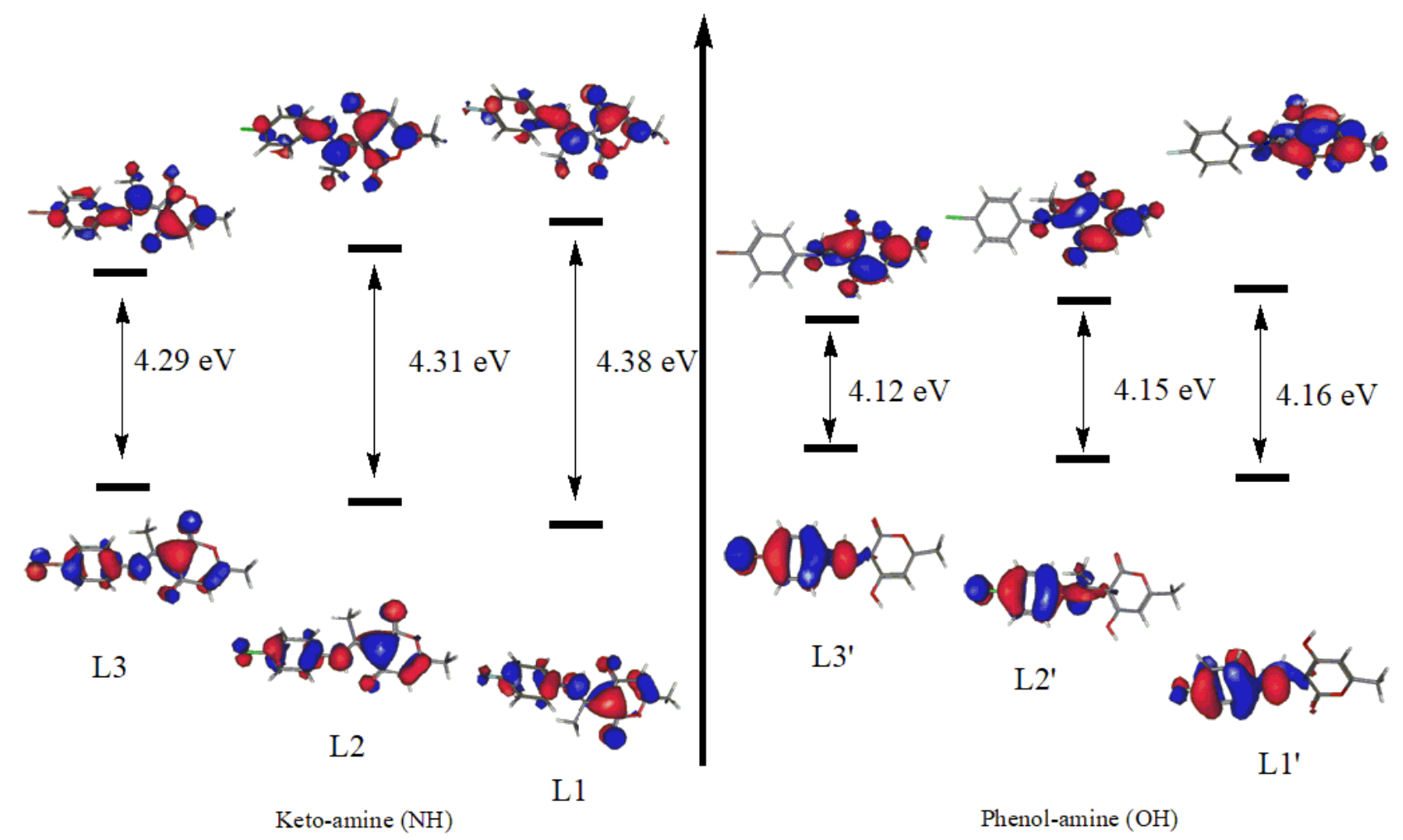

Fig. 5 The frontier molecular orbitals for the two possible tautomeric forms, the keto-amine (NH) L1, L2 and L3 the phenol-imine (OH) forms of the title Schiff base compounds L1', L2' and L3'.HOMOLUMO gap is given.

\subsection{Electronic absorption spectra}


Theoretical UV-visible absorption spectra of L1, L2 and L3 using TDDFT are in clear agreement with experimental results (fig.6). Calculated absorptions with wave length $\lambda(\mathrm{nm})$, oscillator strengths (f) and main transitions with their contribution are illustrated in table 5. L1 exhibits a strong absorption measured at $326 \mathrm{~nm}$ and theoretically obtained at $325 \mathrm{~nm}$ with a main contribution associated to HOMO- $1 \rightarrow$ LUMO and related to $\pi-\pi^{*}$ transition (fig S1 in SI). The absorption band of L2 absorption wave length is found at $331 \mathrm{~nm}$, this band is calculated at $328 \mathrm{~nm}$ and mainly involved the HOMO $\rightarrow$ LUMO transition and is assigned to $\pi-\pi^{*}$ character. The L3 shows an experimental absorption at $330 \mathrm{~nm}$ which was calculated at $328 \mathrm{~nm}$ and attributed to $\mathrm{HOMO} \rightarrow$ LUMO transition with a $\pi-\pi^{*}$ character.

Table 5 : TD-DFT calculated excitations approximate assignments for L1, L2 and L3.

\begin{tabular}{|l|c|c|c|c|c|}
\hline & $\begin{array}{c}\lambda_{\text {Expt. }} \\
(\mathrm{nm})\end{array}$ & $\begin{array}{c}\lambda_{\text {Cal. }} \\
(\mathrm{nm})\end{array}$ & $\begin{array}{c}\text { Oscillator } \\
\text { Strength }\end{array}$ & Assignment & $\begin{array}{c}\text { Contribution } \\
(\text { Coeff } \%)\end{array}$ \\
\hline L1 & 326 & 325 & 0.132 & HOMO-1 $\rightarrow$ LUMO & 39.60 \\
\hline L2 & 331 & 328 & 0.246 & HOMO $\rightarrow$ LUMO & 45.22 \\
\hline L3 & 330 & 328 & 0.303 & HOMO $\rightarrow$ LUMO & 52.22 \\
\hline
\end{tabular}
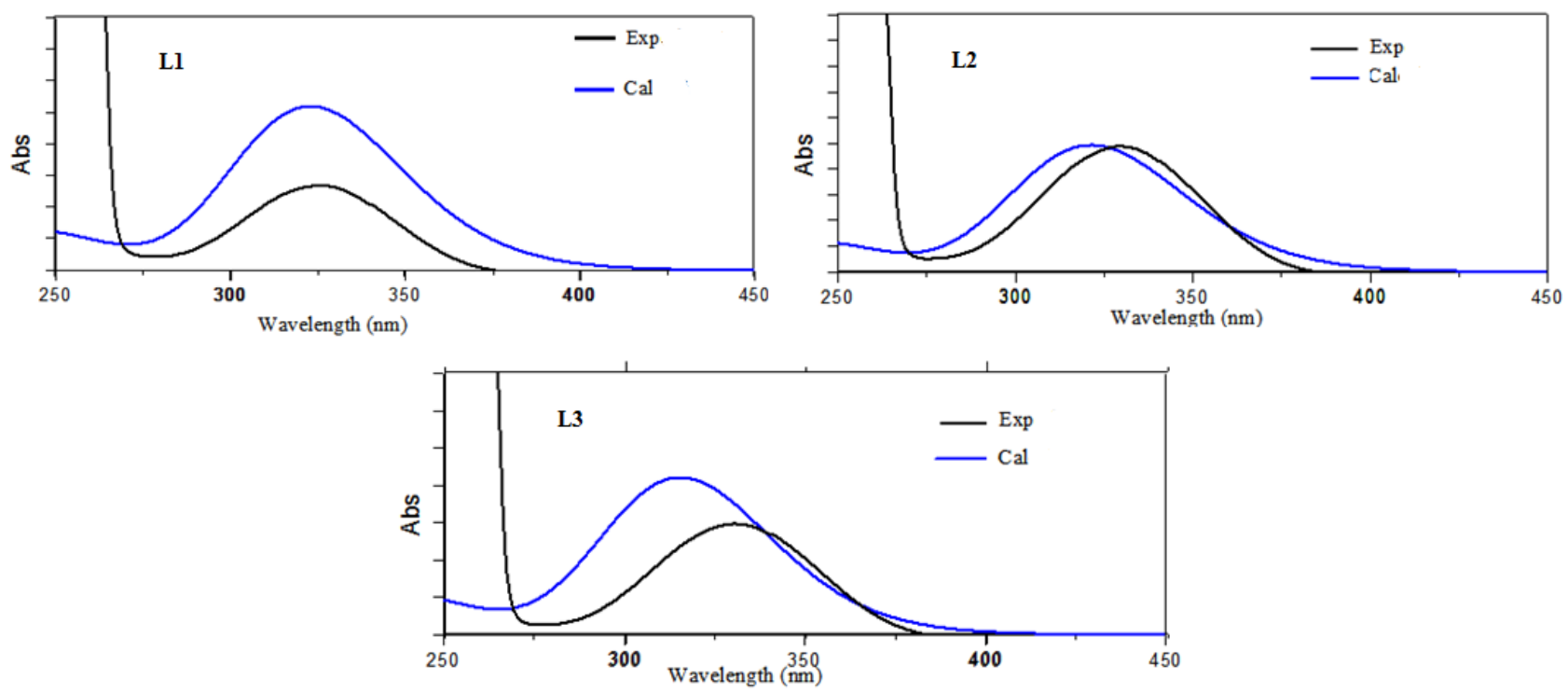

Fig. 6 Experimental and simulated electronic absorption spectra of L1, L2 and L3. 


\subsection{The Hirshfeld surface analysis}

The Hirshfeld analysis reveal the presence of intermolecular interactions(intercontact) in crystalline environment of the titled compounds. The normalized contact distance $d_{\text {norm }}$ between molecules in 3D is a parameter that includes distances of any surface point to the nearest nucleus internal $\left(\mathrm{d}_{\mathrm{i}}\right)$ and the nearest nucleus external to the surface $\left(\mathrm{d}_{\mathrm{e}}\right)$ and the van der Waals radii of atoms $\left(\mathrm{r}^{\mathrm{vdw}}\right)$ given by the equation:

$$
\mathrm{d}_{\text {norm }}=\frac{\mathrm{d}_{\mathrm{i}-\mathrm{r}_{\mathrm{i}}^{\mathrm{vdw}}}}{\mathrm{r}_{\mathrm{i}}^{\mathrm{vdw}}}+\frac{\mathrm{d}_{\mathrm{e}}-\mathrm{r}_{\mathrm{e}}^{\mathrm{vdw}}}{\mathrm{r}_{\mathrm{e}}^{\mathrm{vdw}}}
$$

The value of $d_{\text {norm }}$ is negative or positive when intermolecular contacts are shorter or longer than $\mathrm{r}^{\mathrm{vdW}}$ respectively. The analyses of the Hirshfeld surface and fingerprint plots of the titled compound were obtained using the crystal Explorer 3.0 package [46]. The overall two-dimensional (2D) fingerprint plot of contact $\mathrm{O} \ldots \mathrm{H} / \mathrm{H} \ldots \mathrm{O}$ and $\mathrm{N}$...H/H...N are illustrated in fig. 6.The intermolecular interactions of the $\mathrm{O} \ldots . \mathrm{H} / \mathrm{H}$.... $\mathrm{O}$ contact with a relative contribution of $21.9 \%, 25.5 \%$ and $25.9 \%$ for L3, L2 and L1 respectively have the most significant contribution to the total Hirsfeld surfaces. The spikes point out the dominant interactions for the $\mathrm{O} \ldots \mathrm{H} / \mathrm{H}$...O contact. The contact appears as a pair of sharp spikes where the $\left(\mathrm{d}_{\mathrm{e}}, \mathrm{d}_{\mathrm{i}}\right)$ distributions correspond to $\mathrm{d}_{\mathrm{e}}+\mathrm{d}_{\mathrm{i}} \sim 2.4 \AA, \sim 2.5 \AA$ and $\sim 2.46 \AA$ for $\mathrm{L} 1, \mathrm{~L} 2$ and L3 respectively. These relative small values compared to the sum of the van der Waals radius $(2.72 \AA)$ reflect the relatively strong interaction between $\mathrm{O}$ and $\mathrm{H}$.
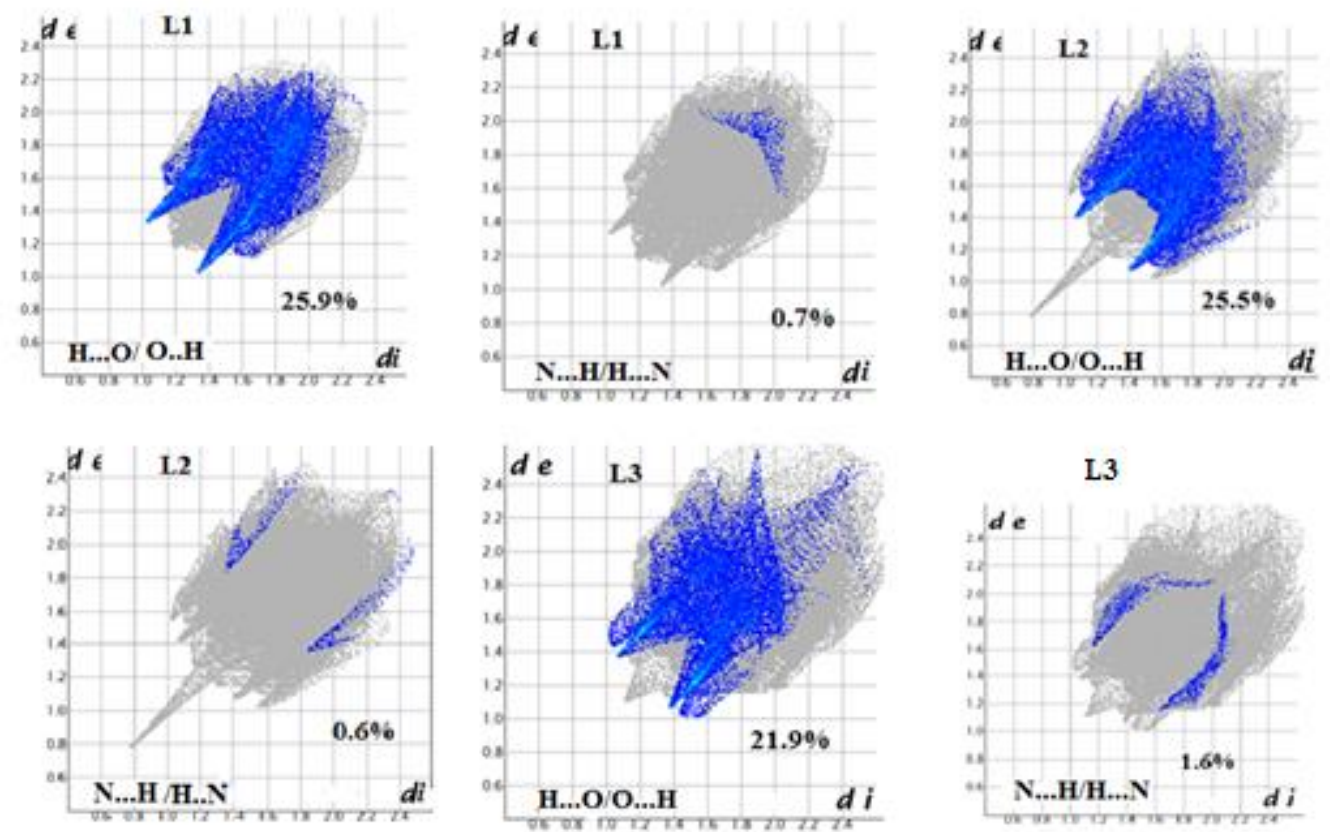

Fig. 7 Two-dimensionalfingerprint plots of L1, L2 and L3 for O..H/H..O and N...H contacts.d $\mathrm{d}_{\mathrm{e}}$ and $d_{i}$ represent the distances from the surface to nearest external and internal atoms. The blue color represents increasing numbers of surface contributors at individual $d_{e} / d_{i}$ points. 

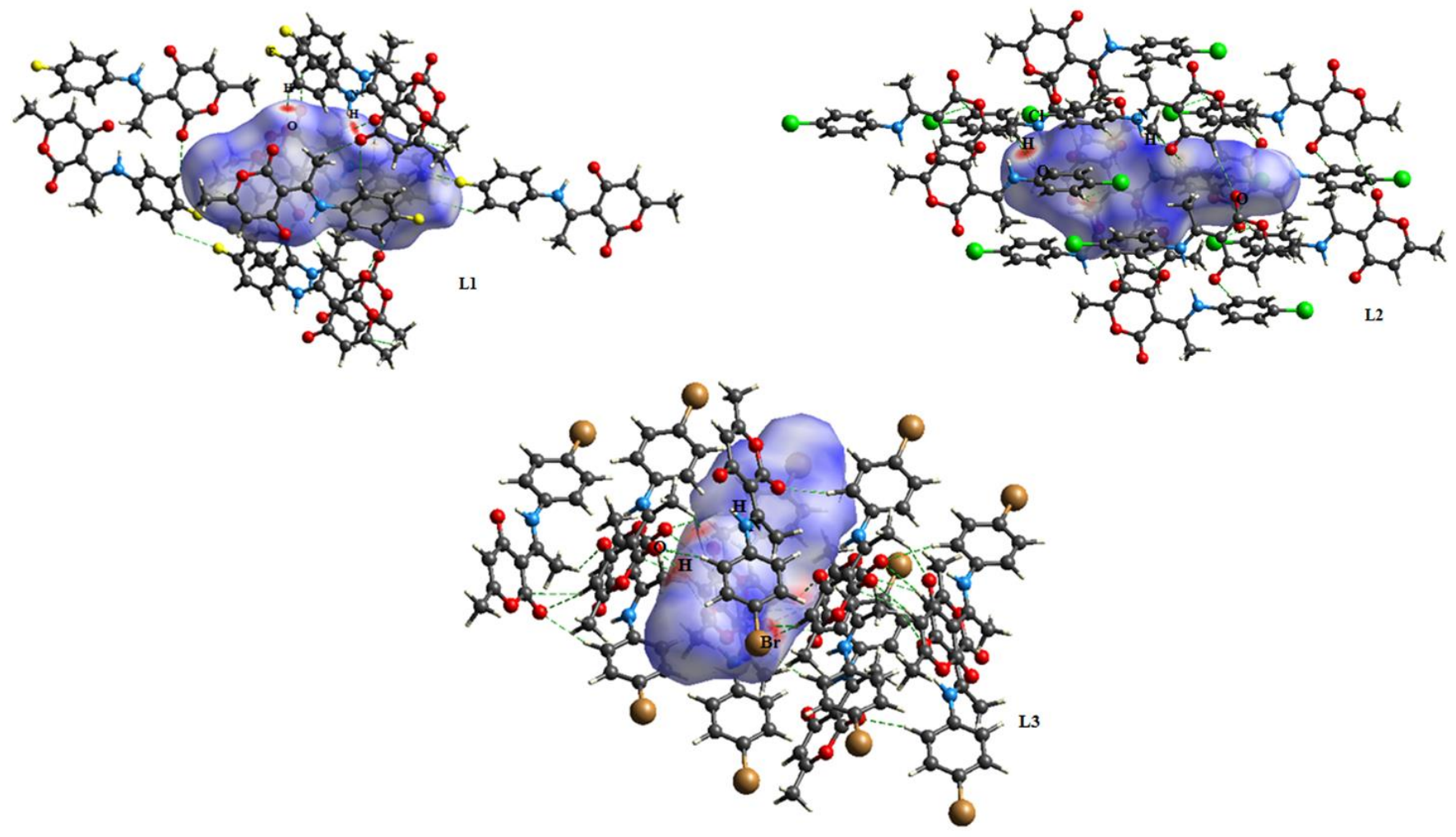

Fig.8 Hirshfeld surfaces for visualizing the intermolecular contacts. The $\mathrm{d}_{\text {norm }}$ values are mapped onto the Hirshfeld surface using a red-blue-white colour scheme as follows: red regions represent closer contacts and a negative $d_{\text {norm }}$ value; blue regions represent longer contacts and a positive $d_{\text {norm }}$ value; and white regions represent the distance of contacts equal to exactly the vdW separation with a $d_{\text {norm }}$ value of zero.

The corresponding regions on the Hirshfeld surface mapped (fig. 7) appear as blue and light-red, respectively in the red region hydrogen acceptors and in the blue region hydrogen donor for providing more detailed information on the intermolecular interaction influential in the crystal. The presence of an intermolecular ionic hydrogen bond $\mathrm{N}^{+}-\mathrm{H}$.... ${ }^{-} \mathrm{O}$ of length $1.634,1.787$ and $1.658 \AA$ A respectively for L1, L2 and L3 leading to the stabilization of zwitterionic form. The NH form becomes zwitterionic since it can facilitate such stabilization. These result verify the zwitterionic character and underline that the molecules are linked by weak C-H....O hydrogen bonds.

\subsection{Catecholase studies}

The progress of the catechol oxidation reaction is conveniently followed monitoring the strong absorbance peak of $o$-quinone in the UV/Vis spectrophotometer (Scheme 2). The metal complex (prepared in situ from metal salt and the ligand) [47] and a solution of catechol were added together 
in the spectrophotometric cell at $25^{\circ} \mathrm{C}[48,49]$. Formation of $o$-quinone was monitored by the increase in absorbance at 390 and $400 \mathrm{~nm}$ as a function of time. Table 6 gives absorbances of $\mathrm{Cu}$ (II) complexes generated in situ after 60 min by mixing metallic salts $\mathrm{Cu}\left(\mathrm{CH}_{3} \mathrm{COO}\right)_{2}, \mathrm{CuBr}_{2}, \mathrm{CuCl}_{2}, \mathrm{Cu}\left(\mathrm{NO}_{3}\right)_{2}$ and $\mathrm{CuSO}_{4}$ and ligands L1-L3 (2/1) and catechol. The oxidation rates are shown in Table 7.

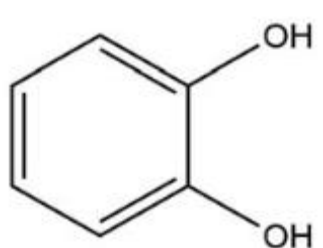

Catechol

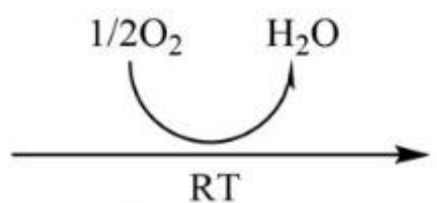

Ligand / Metal

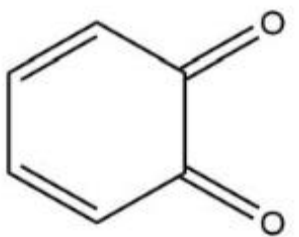

$O$-quinone

Scheme. 2 Catecholase reaction.

We note that the catalytic activity varies from a complex to the other one, the obtained results for $\mathrm{Cu}\left(\mathrm{CH}_{3} \mathrm{COO}\right)_{2}$ salt are grouped in (Fig. 8) and the $\mathrm{V}_{\max }$ rates of the catechol oxidation were calculated in a time range of $5 \mathrm{~min}$ where the slope of the absorbance graph is maximal and collected in Table 6. In this part, we take one equivalent of ligand for two equivalents of metallic salt.

All copper complexes catalyze the oxidation reaction of catechol to o-quinone, but with oxidation rate values ranging from $0.04 \mu \mathrm{mol} \mathrm{L} \mathrm{L}^{-1} \mathrm{~min}^{-1}$ to $20.06 \mu \mathrm{mol} \cdot \mathrm{L}^{-1} \cdot \mathrm{min}^{-1}$. In fact, the first rate concerns the complexes formed from $\mathrm{L} 2$ and metallic salts $\mathrm{CuBr}_{2}$ and $\mathrm{CuCl}_{2}$ (weak catalysts) and the second one concerns the complex formed from $\mathrm{L} 1$ and metallic salt $\mathrm{Cu}\left(\mathrm{CH}_{3} \mathrm{COO}\right)_{2}$ (best catalyst) (Table 7). The difference between the catalytic activities from a complex to another depends strongly on both the structure of the ligand and the action of the anion. Indeed, most ligands have a low absorbance with all the anions except in the case of acetate anion where the values of the absorbance are high (Table 6).

\section{Table 6}

Absorbance of the mixture of $\mathrm{Cu}(\mathrm{II})$ and cathecolafter $60 \mathrm{~min}\left(\mu \mathrm{mol} \mathrm{L} \mathrm{L}^{-1} \mathrm{~min}^{-1}\right)$.

\begin{tabular}{|l|l|l|l|l|l|}
\hline Ligand/metallicsalt & $\mathrm{Cu}\left(\mathrm{CH}_{3} \mathrm{COO}\right)_{2}$ & $\mathrm{CuBr}_{2}$ & $\mathrm{CuCl}_{2}$ & $\mathrm{Cu}\left(\mathrm{NO}_{3}\right)_{2}$ & $\mathrm{CuSO}_{4}$ \\
\hline $\mathrm{L}_{1}$ & 1.928 & 1.418 & 0.945 & 0.3619 & 0.948 \\
$\mathrm{~L}_{2}$ & 1.6937 & 0.0386 & 0.0387 & 0.0961 & 0.2678 \\
$\mathrm{~L}_{3}$ & 1.348 & 1.312 & 0.292 & 0.554 & 0.574 \\
\hline
\end{tabular}




\section{Table 7}

Oxydation rate of cathecoloxydation in methanol ( $\mu$ mol.L'.min).

\begin{tabular}{|l|l|l|l|l|l|}
\hline Ligand/metallicsalt & $\mathrm{Cu}\left(\mathrm{CH}_{3} \mathrm{COO}\right)_{2}$ & $\mathrm{CuBr}_{2}$ & $\mathrm{CuCl}_{2}$ & $\mathrm{Cu}\left(\mathrm{NO}_{3}\right)_{2}$ & $\mathrm{CuSO}_{4}$ \\
\hline $\mathrm{L}_{1}$ & $\mathbf{2 0 . 0 6}$ & 12.34 & 9.83 & 3.73 & 6.18 \\
$\mathrm{~L}_{2}$ & 17.63 & $\mathbf{0 . 4}$ & $\mathbf{0 . 4}$ & 1.00 & 2.79 \\
$\mathrm{~L}_{3} 1$ & 4.04 & 10.97 & 2.36 & 4.91 & 5.96 \\
\hline
\end{tabular}

The differences in activity observed during the oxidation reaction was found to be influenced by: (a) The nature of the anion associated with the metal: the anions that bind tightly with copper cannot be easily displaced by the substrate, thereby reducing the catalytic power as in the case of $\mathrm{NO}_{3}{ }^{-}$, $\mathrm{SO}_{4}^{-}, \mathrm{Cl}^{-}, \mathrm{Br}^{-}$ions. In complexes with anions that form weaker bonds with the metal center, the substrate has no problem to coordinate to the metal because it can easily replace the weakly bound anions and consequently promotes the oxidation reaction of catechol with higher rate as in the case of $\mathrm{CH}_{3} \mathrm{COO}^{-}$.

(b) The nature of the substituent in the para position of the benzene ring : the ligand with the most electronegative substituent provides an important catalytic activity as the complexes of the ligands with substituent less electronegative, the electron attractor group can increase the complexing properties of the ligand [50,51].

\section{Effects of the nature of anion and the ligand}

In the $\mathrm{CH}_{3} \mathrm{COO}$ - case (Fig. 8), all ligands show high values of absorbance in time.In bromides, chlorides, nitrates, and sulfates (Fig. 9 - 12), Cu-L1 complex seams the best oxidation catalyst with a highest value of rate $\left(12.34 \mu \mathrm{mol} \mathrm{L} \mathrm{L}^{-1} \mathrm{~min}^{-1}\right)$, whereas with the other ligands [52,53] the rate values are located in the same gap but are still low within the range of 0.4 and $1 \mu \mathrm{mol} \mathrm{L}^{-1} \mathrm{~min}^{-1}(\mathbf{L} 2)$. The comparison between the catalytic activity of the complexes of copper (II) and the three four ligands $\mathbf{L 1}, \mathbf{L 2}$ and $\mathbf{L 3}$ (Table 6) shows that $\mathrm{Cu}-\mathbf{L} 2$ complexes are observed to be the lowest active, except in the case of $\mathrm{NO}_{3}{ }^{-}$anion. 


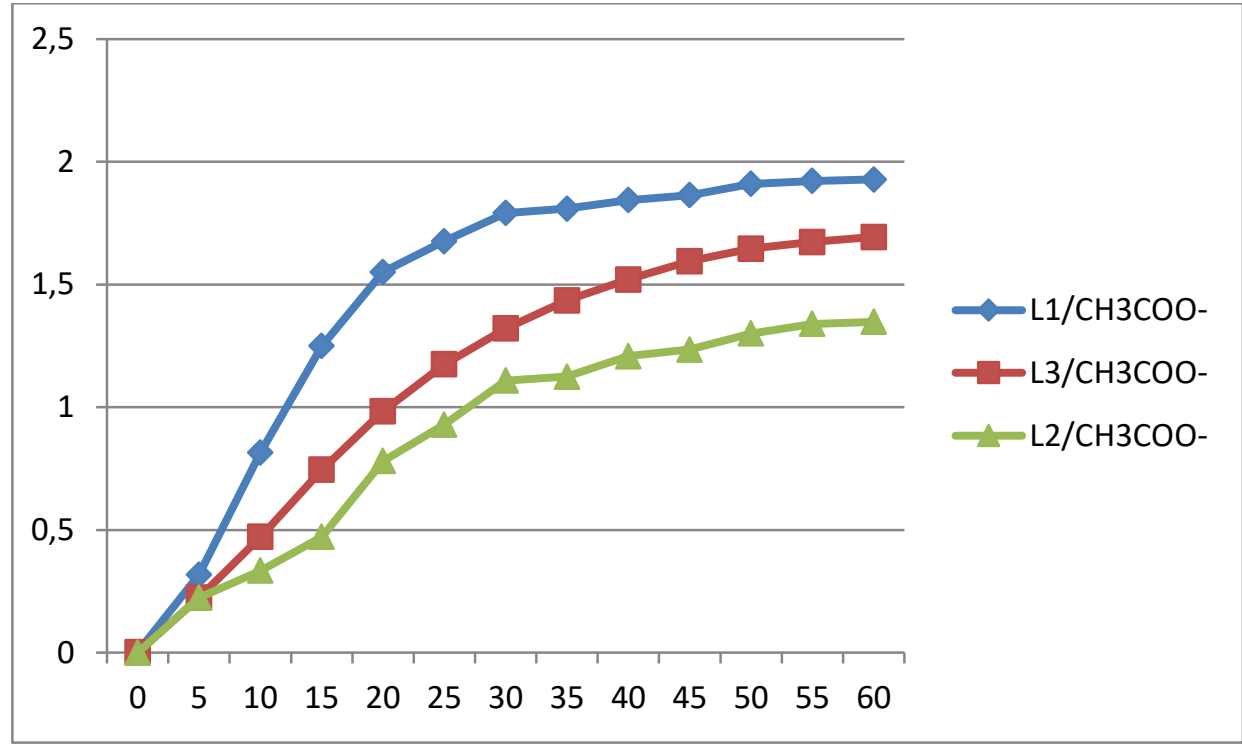

Fig. 9 Oxidation of catechol in presence of acetate.

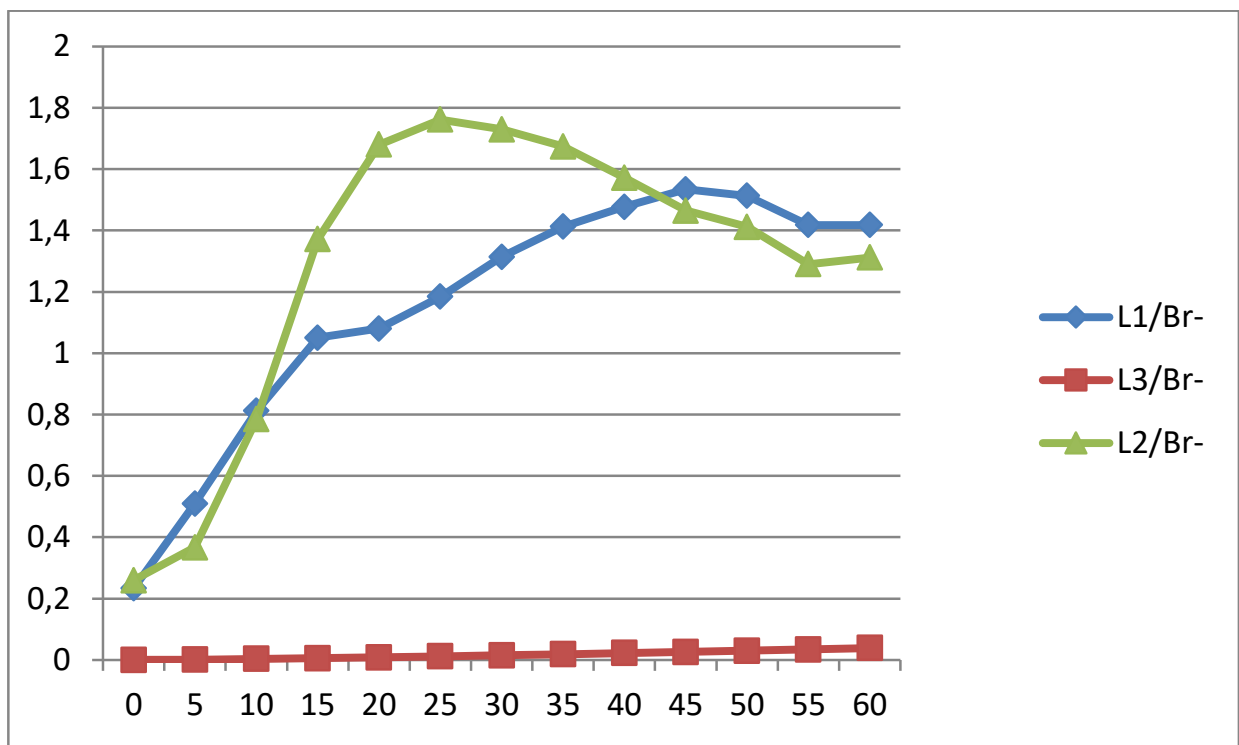

Fig. 10 Oxidation of catechol in presence of bromide. 


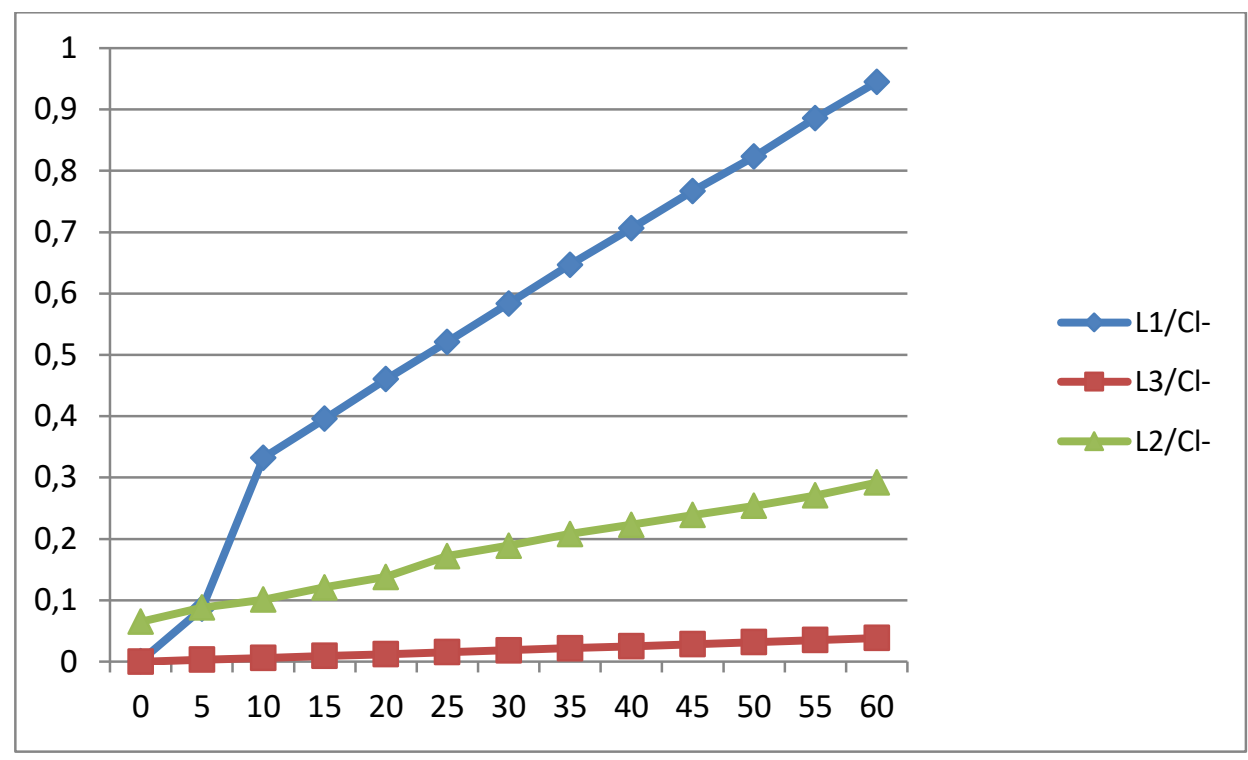

Fig. 11 Oxidation of catechol in presence of chloride.

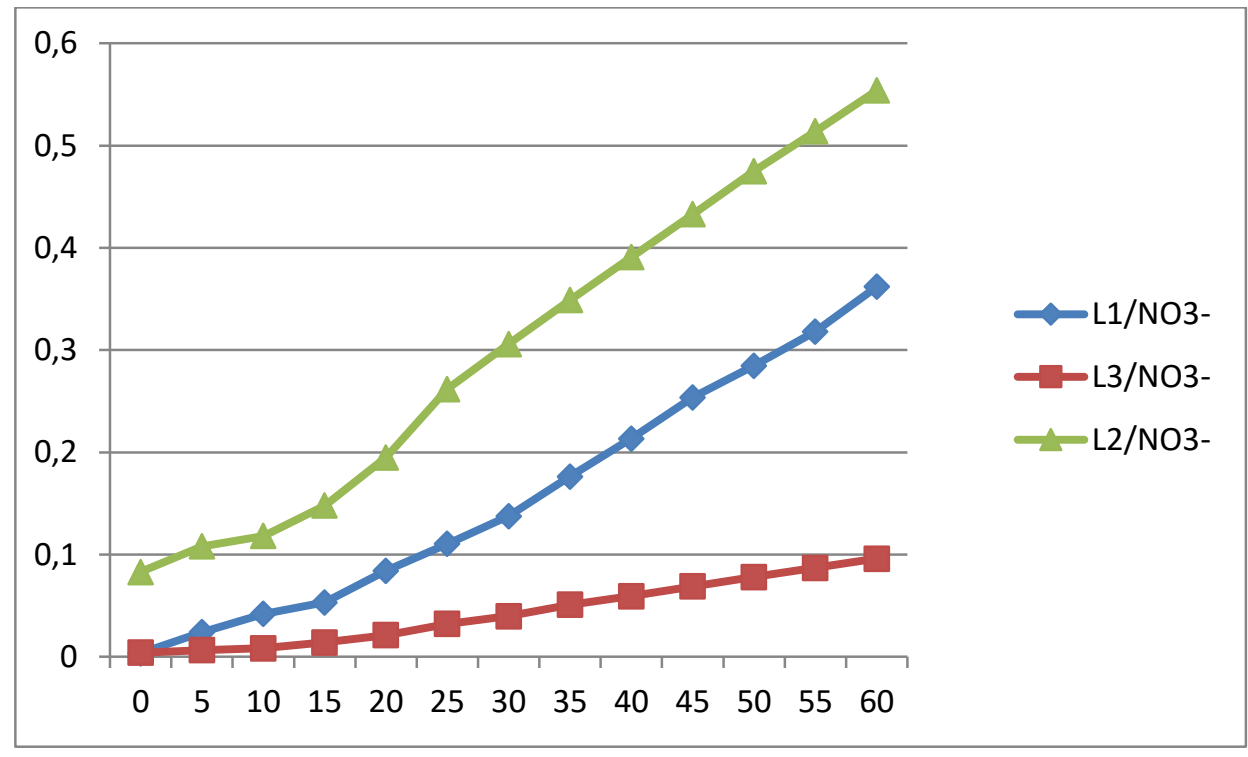

Fig. 12 Oxidation of catechol in presence of nitrate. 


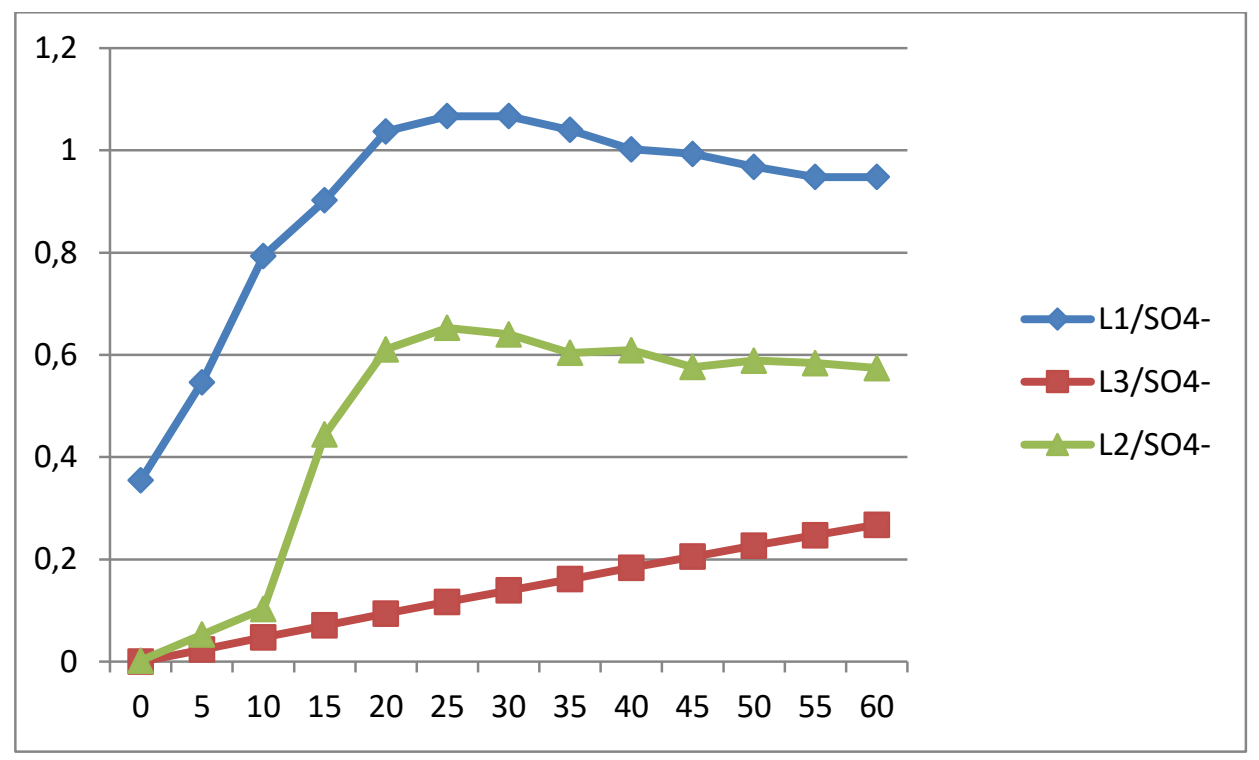

Fig. 13 Oxidation of catechol in the presence of sulfate.

\section{Effects of the ligand concentration on the cathecolaseactivity}

Evolution of catechol oxidation into o-quinone is followed by varying the ratio of equivalent ligand $\mathrm{L} 1 /$ metallic salt $\mathrm{Cu}\left(\mathrm{CH}_{3} \mathrm{COO}\right)_{2}$. Three tests were carried out in ratio: $1 / 1,2 / 1$ and $1 / 2$. The results indicate that the test with the ratio $\mathrm{L} 2 / \mathrm{Cu}\left(\mathrm{CH}_{3} \mathrm{COO}\right)_{2}=3$ leads to the higher oxidation rate value $\left(20.06 \mathrm{mmol} \mathrm{L}^{-1} \mathrm{~min}^{-1}\right)$. For the ratio $1 / 1$, the maximum value of the rate is $15.27 \mathrm{mmolL}^{-1} \mathrm{~min}^{-1}$. For the ratio $2 / 1$, the rate value have reached a maximum of $12.38 \mathrm{mmol} \mathrm{L}^{-1} \mathrm{~min}^{-1}$ (Fig. 13).

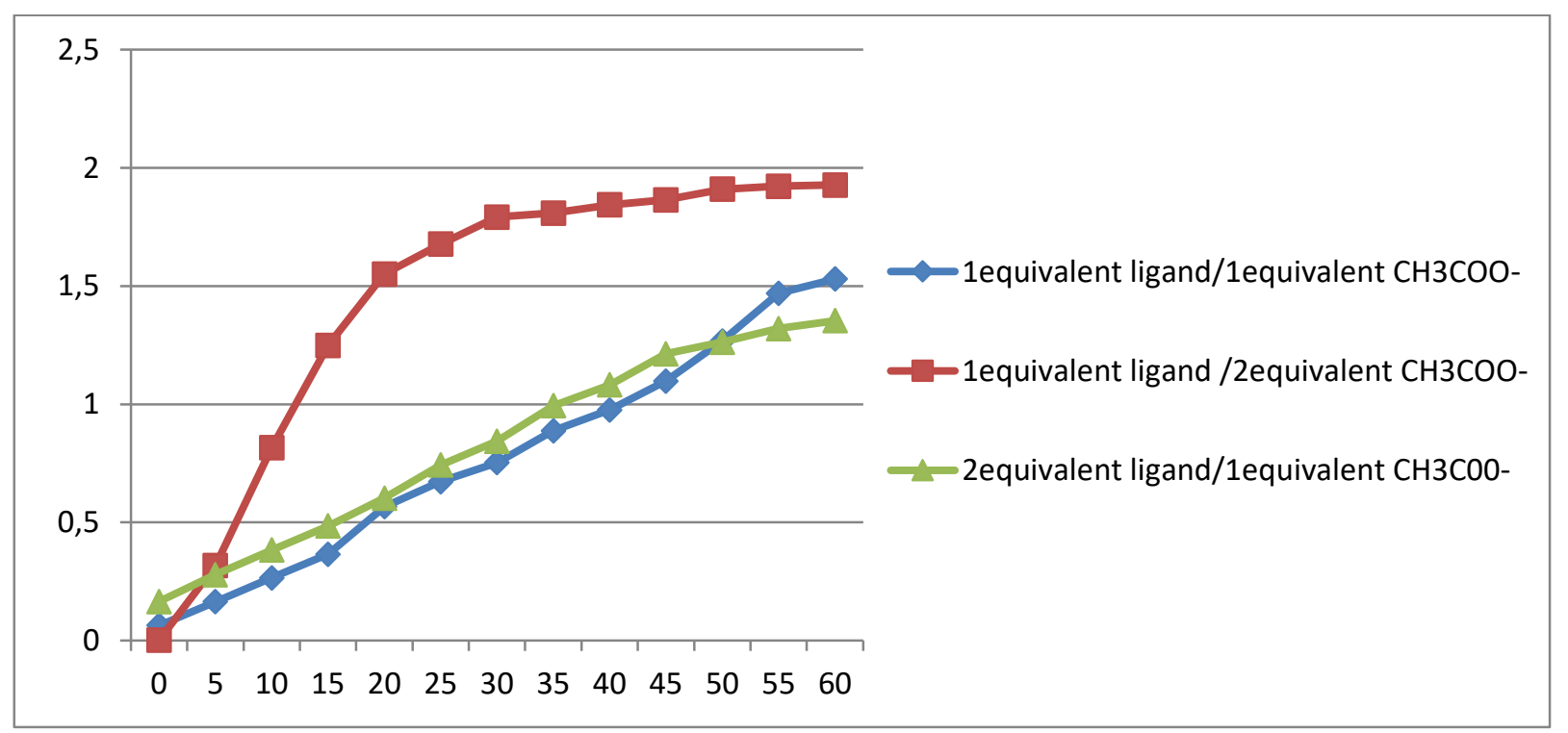

Fig. 14 Catechol oxidation in methanol, in presence of formed L1 copper complexes with different concentrations. 


\section{Conclusion}

We report here the synthesis of three new Schiff bases derivatives of dehydroacetic acid 6-methyl2-oxo-3-[1-(p-fluoriminio)ethyl]-2H-pyran-4-olate (L1),6-methyl-2-oxo-3-[1-(p-chloriminio)ethyl]2H-pyran-4-olate (L2) and 6-methyl-2-oxo-3-[1-(p-bromoriminio)ethyl]-2H-pyran-4-olate (L3), with good yields. The X-ray structures of the three compounds have been investigated for the first time herein. The oxidation reaction of catechol is very efficient to give o-quinone by complexes of copper (II), obtained with the three ligands (L1-L3). Structural and electronic properties have been investigated at DFT/B3LYP level and the analyses of the Hirshfeld surface are in good agreement with the experimental data. Copper (II) complexes were generated in situ and our results show that all the complexes catalyze the aerobic oxidation of catechol to the corresponding o-quinone.

\section{Acknowledgements}

Th eauthors acknowledge the Algerian Ministry of Higher Education and Scientific Research, and the Algerian Directorate General for Scientific Research and Technological Development for support of this work.

\section{References}

[1] R. Villar, I. Encio, M. Migliaccio, M. G. Gil,\&V. Martinez-Merino,Synthesis and cytotoxic activity of lipophilic sulphonamide derivatives of the benzo[b]thiophene 1,1-dioxide, Bioorg. Med. Chem. 12(2004) 963-968.

[2] Y. Li, Z. S. Yang, H. Zhang, B. J. Cao,\& F. D. Wang,Artemisinin derivatives bearing Mannich base group: synthesis and antimalarial activity, Bioorg. Med. Chem. 11(2003) 4363-4368.

[3] A. Kagkelari, G. S. Papaefstahiou, C. P. Raptopoulou,\& T. F. Zafiropoulos,Synthesis and structure of N-salicylidene-o-aminophenolato gallium(III) complexes, Polyhedron.28(2009) 32793283.

[4] A. Ourari, K. Ouari, M. A. Khan,\& G. Bouet,Dioxygen activation with a cytochrome P450 model. Characterization and electrochemical study of new unsymmetrical tetradentate Schiff-base complexes with iron(III) and cobalt(II), J. Coord. Chem.61(2008) 3846-3859.[5] T. Karakurt, A. Cukurovali, N.T. Subasi, I. Kani, Molecular structure and computational studies on 2-((2-(4-(3-(2,5dimethylphenyl)-3-methylcyclobutyl)thiazol-2-yl)hydrazono)methyl)phenol monomer and dimer by DFT calculations, J. Mol. Struct. 1125 (2016) 433-442. 
[6] E. Hadjoudis, M. Vitterakis, I. M. Maviridis,Photochromism and thermochromism of schiff bases in the solid state and in rigid glasses, Tetrahedron.43(1987) 1345-1360.

[7] H. Nazır, M. Yıldız, H. Yılmaz, M.N. Tahir, D. Ülkü,Intramolecular hydrogen bonding and tautomerism in Schiff bases. Structure of N-(2-pyridil)-2-oxo-1-naphthylidenemethylamine, J. Mol. Struct.524(2000) 241-250.

[8] L. Antanov, W.M.F. Fabian, D. Nedeltcheva, F.S. Kamounah,Tautomerism of 2-hydroxynaphth aldehyde Schiff bases, J. Chem. Soc., Perkin Trans.2 (2000) 1173-1179.

[9] T.M. Krygowski, K. Wozniak, R. Anulewicz, D. Pawlak, W. Kolodziejski, E. Grech, A. Szady, Through-Resonance Assisted Ionic Hydrogen Bonding in 5-Nitro- $N$-salicylideneethylamine, J. Phys. Chem. A. 101(1997) 9399-9404.

[10] A. Djedouani, A. Bendaas, S. Boufas, M. Allain, G. Bouet, M. Khan, Zwitterionic (E)-6-methyl2-oxo-3-[1-(p-tolyliminio)ethyl]-2H-pyran-4-olate, Acta Cryst.E63(2007) 1271-1273.

[11] K. Ouari, S. Bendia, M. Merzougui and C. Bailly,1,1'-\{(Hexane-1,6-diyl)bis[(azaniumylylidene)methanylylidene] \}bis(naphthalen-2-olate), Acta Cryst.E71 (2015)o51-o52.

[12] K. Ouari, S.Bendia, M. Merzougui and C. Bailly, Crystal structure of 1,1'-\{(dodecane-1,12-diyl)bis[(azaniumylylidene)methanylylidene] \}bis(naphthalen-2-olate),ActaCryst E. E71(2015)o3510352.

[13] K. Ogawa, J. Harada,Aggregation controlled proton tautomerization in salicylideneanilines, J. Mol. Struc.647(2003)211-216.

[14] K.H. Reddy, P.S. Reddy, P.R. Babu,Nuclease activity of mixed ligand complexes of copper(II) with heteroaromatic derivatives and picoline, Transition Met. Chem. 25 (2000) 505-510.

[15] S. Sreedaran, K. Bharathi, A. Rahiman, K. Rajesh, G. Nirmala, V. Narayanan,Synthesis, spectral, magnetic, electrochemical and catalytic studies of cyclam-based copper(II) and nickel(II) complexeseffect of N-substitution,J. Coord. Chem. 61 (2008) 3594-3609.

[16] A. Allam, I. Dechamps-Olivier, J. B. Behr, L. Dupont, R. Plantier-Royon,Thermodynamic, spectroscopic studies and catechol oxidase activity of copper (II) complexes with amphiphilic dgalacturonic acid derived ligands,Inorg. Chim. Acta.366 (2011) 310-319.

[17] A. Djedouani, F. Abrigach, M. Khoutoul, A. Mohamadou, A. Bendaas, A.Oussaid, R. Touzani, Catecholase Activity Investigations using in situ Copper Complexes Continuing Schiff Base Derivatives with a Theoretical Calculation, Orient J Chem.31(2015) 97-105.

[18]A. Mouadili, F.F. Al-blewi, N. Rezki, M. Messali, A. El Ouafi, R. Touzani, Biomimetic catecholase studies: using in-situ prepared complexes by 1,2,4-triazole schiff bases and different metal salts, J. Mater. Environ. Sci., 6(2015) 2392-2399. 
[19] A. Mouadili, I. Lakehal, A. Takfaoui, F. Halaimia, H. Nacer, M.L. Hamlaoui, B. Hammouti, M. Messali, R.J. Touzani, Air Oxidation of catechol by in-situ copper (II) complexes with ligands containing benzyl groups, Mater. Environ. Sci.5 (2014) 715-722.

[20] A. Zerrouki, R. Touzani, S. El Kadiri, Synthesis of new derivatizedpyrazole based ligands and Theircatecholase activity studies, Arab. J. Chem.4(2011) 459-464.

[21] M.C. Burla, R. Caliandro, M. Camalli, B. Carrozzini, G.L. Cascarano, L.DeCaro, C. Giacovazzo, G. Polidori, R. Spagna,SIR2004: an improved tool for crystal structure determination and refinement, J. Appl. Cryst.38 (2005)381-390.

[22] G.M. Sheldrick. SHELX97 - Program for Crystal Structure Analysis (Release 97 2), Göttingen (1998); (b) Bruker-AXS. SAINT and SADABS, Bruker Analytical X-ray Systems Inc., Madison, W1 (2009).

[23] W. Kohn, L.J. Sham, Self-Consistent Equations Including Exchange and Correlation Effects, Phys. Rev.140 (1965)A1133.

[24] M.J. Frisch, G.W. Trucks, H.B. Schlegel, G.E. Scuseria, M.A.n Robb, J.R. Cheeseman, G. Scalmani, V. Barone, B. Mennucci, G.A. Petersson, H. Nakatsuji, M. Caricato, X. Li, H.P. Hratchian, A.F. Izmaylov, J. Bloino, G. Zheng, J.L. Sonnenberg, M. Hada, M. Ehara, K. Toyota, R. Fukuda, J. Hasegawa, M. Ishida, T. Nakajima, Y. Honda, O. Kitao, H. Nakai, T. Vreven, J.A. Montgomery, Jr, J.E. Peralta, F. Ogliaro, M. Bearpark, J.J. Heyd, E. Brothers, K.N. Kudin, V.N. Staroverov, R. Kobayashi, J. Normand, K. Raghavachari, A. Rendell, J.C. Burant, S.S. Iyengar, J. Tomasi, M. Cossi, N. Rega, J.M. Millam, M. Klene, J.E. Knox, J.B. Cross, V. Bakken, C. Adamo, J. Jaramillo, R. Gomperts, R.E. Stratmann, O. Yazyev, A.J. Austin, R. Cammi, C. Pomelli, J.W. Ochterski, R.L. Martin, K. Morokuma, V.G. Zakrzewski, G.A. Voth, P. Salvador, J.J. Dannenberg, S. Dapprich, A.D. Daniels, O. Farkas, J.B. Foresman, J.V. Ortiz, J. Cioslowski, D.J. Fox, Gaussian Inc, Wallingford, CT, (2009).

[25] A.D. Becke, Density-functional thermochemistry. III. The role of exact exchange, J. Chem. Phys.98 (1993) 5648-5652.

[26] C. Lee, W. Yang, R.G. Parr, Development of the Colle-Salvetti correlation-energy formula into a functional of the electron density, Phys. Rev. B. 37(1988)785-789.

[27] G. A. Petersson, M. A. Al-Laham, A complete basis set model chemistry. II. Open-shell systems and the total energies of the first-row atoms, J. Chem. Phys. 94(1991) 6081-6090.

[28] L. Calero, A. Vega, A.M. Garcia, E. Spodine, J. Manzur, Oxidation and catalytic properties of a binuclear copper(i) complex with a meta-xylyl spacer ligand, J. Chil. Chem. Soc. 48 (2003) 85-88. 
[29]S. Özkar, D. Ülkü, L. T. Yildirim, N. Biricik, B. Gümgüm. Crystal and molecular structure of bis(acetylacetone)ethylenediimine: intramolecular ionic hydrogen bonding in solid state,J. Mol. Struc.688 (2004) 207-211.

[30] M. Gavranic, B. Kaitner, E. Mestrovis, Intramolecular N-H...O hydrogen bonding, quinoid effect, and partial $\pi$-electron delocalization in $\mathrm{N}$-aryl Schiff bases of 2-hydroxy-1-naphthaldehyde: the crystal structures of planar N-( $\alpha$-naphthyl) and N-( $\beta$-naphthyl)-2-oxy-1-naphthaldimine, J. Chem. Crystallogr. 26 (1996) 23-28.

[31] H.H. Freedman, Intramolecular H-Bonds. I. A Spectroscopic Study of the Hydrogen Bond between Hydroxyl and Nitrogen, J. Am. Chem. Soc. 83 (1961) 2900-2905.

[32] S.F. Tan, K.P. Ang, H.L. Jatchandran, Synthesis and characterisation of copper(II), nickel(II) and palladium(II) complexes of some schiff bases of dehydroacetic acid, Trans. Met. Chem., 9 (1984), 390-395

[33] O. Carugo, C.B. Castellani and M. Rizzi, Influence of the complexation of copper(II) on the structure and reactivity of 4-hydroxy-6-methyl-3-[3-dimethylaminoacryloyl]-2H-pyran-2-one, Polyhedron.9 (1990) 2061-2069.

[34] S. M. Emam, A. S. El-Tabl, H. M. Ahmed, E. A. Emad, Synthesis, structural characterization, electrochemical and biological studies on divalent metal chelates of a new ligand derived from pharmaceutical preservative, dehydroacetic acid, with 1,4-diaminobenzene, Arab J Chem. 10 (2017) s3816-s3825.

[35] A. Djedouani, S. Boufas, M. Allain, G. Bouet and M. Khan, Zwitterionic 6-methyl-2-oxo-3-[1-(ureidoiminio)ethyl]-2H-pyran-4-olatemonohydrate, ActaCryst. E71(2008) o1785.

[36] G. Wojciechowski, M. Ratajczak-Sitarz, A. Katrusiak, W. Schilf, P. Przybylski, B. Brzezinski, Crystal structure of Schiff base derivative of 2,2'-dihydroxybiphenyl-3-carbaldehyde with nbutylamine, J. Mol. Struc. 650(2003) 191-199.

[37] C.R. Girija, N.S. Begum,1-Dimethylamino-3-dimethyliminio-2-(p-methoxyphenyl)prop-1-ene perchlorate,Acta Cryst.E60(2004)0535-0536.

[38] C.R. Girija, N.S. Begum, M.A.Sridhar, N.K. Lokanath, J.S. Prasad,1-Dimethylamino-3-dimethylimino-1-phenylprop-1-ene perchlorate, Acta Cryst. E60(2004) o586-o588.

[39] A. Salhin, A.R. Norfarhah, I.A. Rahman,1-[(Bromomethyl)(phenyl)methylene]-2-(2,4dinitrophenyl)hydrazine, Acta Cryst. E65(2009)o1221-o1222.

[40] B. T. Gowda, S. Foro, H. Fuess, N-(4-Chlorophenyl)acetamide, Acta Cryst. E63(2007)o3392. 
[41] F.H. Allen, O. Kennard, D.G. Watson, L. Brammer, A.G. Orpen, R. Taylor, Tables of bond lengths determined by X-ray and neutron diffraction. Part 1. Bond lengths in organic compounds, J. Chem. Soc., Perkin Trans.II, (1987) S1-S19.

[42] H. Petek, Ç. Albayrak, E. Ağar, H. Kalkan,(Z)-6-[(2-Fluorophenyliminio)methylene]-2,3dihydroxyphenolate, Acta Cryst. E62(2006) 3685-3687.

[43] J. Bernstein, R.E. Davis, L. Shimoni, N.L. Chang, Patterns in Hydrogen Bonding: FunctionalityandGraph Set Analysis in Crystals,Angew. Chem. Int. Ed. Engl.34(1995) 1555-1573. [44] L. Huang, D.B. Chen, D. Qiu, B. Zhao,(E)-2,4-Dichloro-6-[(2-hydroxyethyliminio)methyl]phenolate, Acta Cryst.E62(2006)o5239-o5240.

[45] E. Temel, Ç. Albayrak, O. Büyükgüngőr, M. Odabaşoğlu,Zwitterionic (E)-2-hydroxy-6-[(otolyliminio)methyl]phenolate 0.07-hydrate, Acta Cryst. E62(2006)o4484-04486.

[46] S.K.Wolff, D.J.Grimwood, J.J. Mckinnon, M.J.Turner, D.Jayatilaka, M.A.Spackman, Crystal Explorer, Version 3.0.University of Western Australia (2012).

[47] M. El Kodadi, F. Malek, R. Touzani, A. Ramdani, Synthesis of new tripodal ligand 5-(bis(3,5dimethyl-1H-pyrazol-1-ylmethyl)amino)pentan-1-ol, catecholase activities studies of three functional tripodalpyrazolyl N-donor ligands, with different copper (II) salts, Catal. Commun. 9 (2008) 966-969.

[48] I. Bouabdallah, R. Touzani, I. Zidane, A. Ramdani, Synthesis of new tripodal ligand: N,Nbis[(1,5-dimethylpyrazol-3-yl)methyl]benzylamine. Catecholase activity of two series of tripodal ligands with some copper (II) salts, Catal. Commun.8 (2007) 707-712.

[49] N. Boussalah, R. Touzani, I. Bouabdallah, S. El Kadiri, S. Ghalem,Synthesis, structure and catalytic properties of tripodal amino-acid derivatizedpyrazole-based ligands, J. Mol. CatalA: Chem.306 (2009) 113-117.

[50] A.Mouadili1, S. Chtita, A. El Ouafi, M.Bouachrine, A. Zarrouk, R. Touzani, Biomimetic catecholase activities by prepared in-situ complexes: development of a quantitative, J. Mater. Environ. Sci. 7 (2016) 210-221.

[51] R. Boyaala, R. El Ati, M. Khoutoul, M. El Kodadi, R. Touzani, B. Hammouti,Biomimetic oxidation of catechol employing complexes formed in situ with heterocyclic ligands and diferent copper(II) salts. J. Iran. Chem. Soc. 15 (2018) 85-92

[52] S. Thabti, A. Djedouani, S. Rahmouni, R. Touzani, A. Bendaas, H. Mousser, Synthesis, X-ray crystal structures and catecholase activity investigation of new chalcone ligands, J. Mol. Struc. 1102(2015) 295-301. 
[53] Z. Bouanane, M. Bounekhel, M. Elkolli, F. Abrigach, M. Khoutoul, R. Bouyala, R. Touzani, A. Hellal, Synthesis, structural, catecholase, tyrosinase and DFT studies of Pyrazoloquinoxaline derivatives, J. Mol. Struc. 1139 (2017) 238-246. 